\title{
Orientational Dependence of Cofacial Porphyrin-Quinone Electronic Interactions within the Strong Coupling Regime
}

\author{
Youn K. Kang, ${ }^{\ddagger}$ \& Peng Zhang, ${ }^{\dagger *}$ Igor V. Rubtsov, ${ }^{\ddagger}$,a Jieru Zheng, ${ }^{\dagger, b}$ George \\ Bullard, ${ }^{\dagger}$ David N. Beratan, ${ }^{\dagger}$ and Michael J. Therien ${ }^{\dagger *}$
}

Department of Chemistry, University of Pennsylvania, Philadelphia, Pennsylvania, 19104

${ }^{\S}$ Department of Chemistry, Sangmyung University, Seoul 03016, Korea

†Department of Chemistry, Duke University, Durham, North Carolina, 27707

\section{Corresponding Authors}

*E-mail: peng.zhang@duke.edu; michael.therien@duke

*Phone: (919) 660-1675 (P.Z.); (919) 660-1670 (M.J.T.)

Present Addresses: (a) Department of Chemistry, Tulane University, New Orleans, Louisiana 70118, United States; (b) Division of Analysis, Planning and Monitoring, UNICEF Headquarters, New York 10017, United States.

\section{Contents}

1) Materials and Instrumentation $\quad$ S2

2) Synthetic Procedures and Characterization $\quad$ S3

3) Analysis of Electronic Absorption Spectra $\quad$ S9

4) Femtosecond Laser Spectrometer and Transient Dynamical Data $\quad$ S14

5) Theoretical Analysis $\quad$ S17

5) References $\quad$ S49 
Materials. All manipulations were carried out under nitrogen previously passed through an $\mathrm{O}_{2}$ scrubbing tower (Schweizerhall R3-11 catalyst) and a drying tower (Linde 3- $\AA$ molecular sieves) unless otherwise noted. Air-sensitive solids were handled in a Braun 150-M glove box. Standard Schlenk techniques were employed to manipulate air sensitive solutions. All solvents utilized in this work were obtained from Fisher Scientific (HPLC grade). Tetrahydrofuran (THF), toluene, and 1,2-dimethoxyethane (DME) were dried over K/benzoylbiphenyl, while $\mathrm{CH}_{2} \mathrm{Cl}_{2}$ was dried over $\mathrm{CaH}_{2}$; these solvents were subsequently distilled from these reagents under nitrogen. $\mathrm{Ba}(\mathrm{OH})_{2} \bullet 8 \mathrm{H}_{2} \mathrm{O}$ (Aldrich) was recrystallized from $\mathrm{H}_{2} \mathrm{O}$. $\mathrm{Zn}(\mathrm{OAc})_{2} \bullet 2\left(\mathrm{H}_{2} \mathrm{O}\right)$ was used as received from Fisher Scientific. The catalyst, $\mathrm{Pd}\left(\mathrm{PPh}_{3}\right)_{4}$, was obtained from Strem. (1Iodo-8-[4'- (8', -[2',', 5','-dimethoxyphenyl]-1' '-naphthyl)-1'-phenyl]naphthalene and [2bromo-5,10,15,20-tetraphenylporphinato]zinc(II) were prepared as reported previously. ${ }^{1-5}$ Chromatographic purification (Silica Gel 60, 230-400 mesh, EM Science) of all compounds was performed on the bench top. Chemical shifts for ${ }^{1} \mathrm{H}$ NMR spectra are relative to residual protium in the deuterated solvents $\left(\mathrm{CDCl}_{3}, \delta=7.24 \mathrm{ppm}, \mathrm{C}_{6} \mathrm{D}_{6}, \delta=7.28 \mathrm{ppm}, \mathrm{CD}_{2} \mathrm{Cl}_{2}, \delta=5.32 \mathrm{ppm}\right)$. All coupling constants are reported in Hertz.

\section{Instrumentation. Electronic spectra were recorded on an OLIS UV/vis/NIR} spectrophotometry system that is based on the optics of a Cary 14 spectrophotometer. NMR spectra were recorded on either a 500-MHz or a 400-MHz AC-Bruker spectrometer. Mass spectral data were obtained at the University of Pennsylvania Mass Spectrometry Laboratory located within the Department of Chemistry. 


\section{Synthetic Procedures and Characterization}

\section{[2-(4',4',5',5'-Tetramethyl[1',3',2']dioxaborolan-2'-yl)-5,10,15,20-tetraphenylporphinato]}

zinc(II) (TPPZnB). ${ }^{6}$ A $50 \mathrm{ml}$ Schlenk flask was charged with (2-bromo-5, 10,15,20-

tetraphenylporphinato)zinc(II) $(416 \mathrm{mg}, 0.55 \mathrm{mmol}),{ }^{1-5}$ pinacolborane $(0.8 \mathrm{ml}, 5.5 \mathrm{mmol})$,

triethylamine (0.8 ml, $5.75 \mathrm{mmol}$ ), trans-dichlorobis(triphenylphosphine)palladium(II) (39 ml, $0.055 \mathrm{mmol}$ ) and $15 \mathrm{ml}$ of 1,2-dichloroethane under nitrogen. The mixture was stirred at $90^{\circ} \mathrm{C}$ for $2 \mathrm{~h}$, at which point TLC showed that the (2-bromo-5,10,15,20-tetraphenylporphinato)zinc(II) starting material was completely consumed. The reaction was quenched with aq. $\mathrm{KCl}(10 \mathrm{ml})$, washed with water, and dried over $\mathrm{MgSO}_{4}$. The solvent was evaporated, and the residue taken up in $\mathrm{CH}_{2} \mathrm{Cl}_{2}$; compound TPPZnB was purified by silica gel chromatography using 9:1 hexanes:THF as the eluent. The first band isolated corresponded to $(5,10,15,20-$ tetraphenylporphinato)zinc(II), while the second band contained the porphyrylboronated complex; isolated yield $=380 \mathrm{mg}(86 \%$ based on $416 \mathrm{mg}$ of $(2$-bromo-5,10,15,20tetraphenylporphinato)zinc(II)). ${ }^{1} \mathrm{H}$ NMR (500 MHz, $\left.\mathrm{CDCl}_{3}\right): \delta 9.25$ (s, $\left.1 \mathrm{H}, \mathrm{H}_{\beta}\right), 8.90(\mathrm{~d}, 1 \mathrm{H}$, $\left.\mathrm{J}=4.55 \mathrm{~Hz}, \mathrm{H}_{\beta}\right), 8.88\left(\mathrm{~d}, 1 \mathrm{H}, \mathrm{J}=4.60 \mathrm{~Hz}, \mathrm{H}_{\beta}\right), 8.84\left(\mathrm{~d}, 1 \mathrm{H}, \mathrm{J}=4.77 \mathrm{~Hz}, \mathrm{H}_{\beta}\right), 8.71(\mathrm{~d}, 1 \mathrm{H}, \mathrm{J}=4.56$ $\left.\mathrm{Hz}, \mathrm{H}_{\beta}\right), 8.26-8.19$ (m, $\left.8 \mathrm{H}, \mathrm{H}_{\text {phenyl }}\right), 7.78-7.67$ (m, $\left.12 \mathrm{H}, \mathrm{H}_{\text {phenyl }}\right), 1.23$ (s, $\left.12 \mathrm{H}, \mathrm{H}_{\text {methyl }}\right) .{ }^{13} \mathrm{C}$ $\operatorname{NMR}\left(500 \mathrm{MHz}, \mathrm{CDCl}_{3}\right): \delta 152.52,151.00,150.26,150.22,150.16,150.11,150.06,149.43$, $144.18,143.01,142.99,141.54,135.86,134.71,134.50,134.45,132.77,131.91$ (br), 131.82 (br), $131.55,127.52,127.41,127.36$ (br), 127.33, 126.53, 126.48, 126.45, 126.42, 122.59, 121.00, $120.89,120.74,120.70,107.45,97.10,83.67,25.38{ }^{11} \mathrm{~B} \mathrm{NMR}\left(400 \mathrm{MHz}, \mathrm{CDCl}_{3}\right): \delta 21.68 \mathrm{Vis}$ $\left(\mathrm{CH}_{2} \mathrm{Cl}_{2}\right),\left[\lambda_{\max }(\mathrm{nm}),\left(\log \varepsilon\left(\mathrm{M}^{-1} \mathrm{~cm}^{-1}\right)\right]: 422\right.$ (5.61), 515 (3.68), 551 (4.34), 590 (3.57). HRMS (ESI+) m/z: 802.2441(calcd for $\mathrm{C}_{50} \mathrm{H}_{39} \mathrm{BN}_{4} \mathrm{O}_{2} \mathrm{Zn}(\mathrm{M}+)$ 802.2458. 


\section{[2-[8'-(2",5"-Dimethoxyphenyl)-1'-naphthyl]-5,10,15,20-tetraphenylporphinato]zinc (II)}

(1ß-ZnM). A $50 \mathrm{~mL}$ Schlenk tube was charged with [2-(4',4',5',5'-

tetramethyl[1',3',2']dioxaborolan-2'-yl)-5,10,15,20-tetraphenylporphinato]zinc(II) (160 mg, 0.2 mmol), 1-iodo-8-(2,5-dimethoxyphenyl)naphthalene $(39 \mathrm{mg}, 0.1 \mathrm{mmol}),{ }^{7} \mathrm{Ba}(\mathrm{OH})_{2} \bullet 8 \mathrm{H}_{2} \mathrm{O}(63$ $\mathrm{mg}, 0.2 \mathrm{mmol})$, and $\mathrm{Pd}\left(\mathrm{PPh}_{3}\right)_{4}(6 \mathrm{mg}, 0.05 \mathrm{mmol})$. A degassed mixture of DME $(10 \mathrm{~mL})$ and water $(1 \mathrm{~mL})$ was transferred via cannula into the reaction vessel. After heating at $80{ }^{\circ} \mathrm{C}$ for $2 \mathrm{~h}$, the reaction mixture was partitioned with benzene $(50 \mathrm{ml})$ and aq. $\mathrm{NaCl}(50 \mathrm{ml})$. The organic layer was washed with aq. $\mathrm{NaCl}(3 \times 50 \mathrm{~mL})$ and $\mathrm{H}_{2} \mathrm{O}(50 \mathrm{~mL})$, dried over $\mathrm{CaCl}_{2}$, filtered, and volatiles were removed by vacuum evaporation. The crude material was adsorbed on silica gel (10 g) and chromatographed on silica gel (9:1 hexanes:THF). The first band was TPPZn. The second band was diastereomer A (1/ $\mathbf{Z} \mathbf{Z n A} \mathbf{A}-\mathbf{M})$ which eluted prior to the diastereomer B; isolated

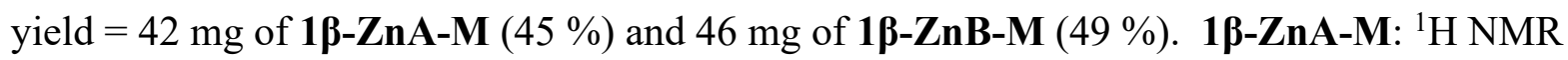
$\left(500 \mathrm{MHz}, \mathrm{CDCl}_{3}\right): \delta 8.94\left(\mathrm{~s}, 2 \mathrm{H}, \mathrm{H}_{\beta}\right), 8.90\left(\mathrm{~d}, 1 \mathrm{H}, \mathrm{J}=4.56 \mathrm{~Hz}, \mathrm{H}_{\beta}\right), 8.88(\mathrm{~d}, 1 \mathrm{H}, \mathrm{J}=4.55 \mathrm{~Hz}$, $\left.\mathrm{H}_{\beta}\right), 8.70\left(\mathrm{~d}, 1 \mathrm{H}, \mathrm{J}=4.65 \mathrm{~Hz}, \mathrm{H}_{\beta}\right), 8.67\left(\mathrm{~s}, 1 \mathrm{H}, \mathrm{H}_{\beta}\right), 8.52\left(\mathrm{~d}, 1 \mathrm{H}, \mathrm{J}=4.70 \mathrm{~Hz}, \mathrm{H}_{\beta}\right), 8.70(\mathrm{~d}, 1 \mathrm{H}$, $\left.\mathrm{J}=7.51 \mathrm{~Hz}, \mathrm{H}_{\text {phenyl }}\right), 8.25-8.20\left(\mathrm{~m}, 4 \mathrm{H}, \mathrm{H}_{\text {phenyl }}\right), 8.08$ (d, $\left.1 \mathrm{H}, \mathrm{J}=7.50 \mathrm{~Hz}, \mathrm{H}_{\text {phenyl }}\right), 8.05-7.95$ (m, 1 H, $\left.\mathrm{H}_{\text {phenyl }}\right), 7.96$ (dd, $\left.1 \mathrm{H}, \mathrm{J}=6.85,1.34 \mathrm{~Hz}, \mathrm{H}_{\text {naphthyl }}\right), 7.80-7.72\left(\mathrm{~m}, 9 \mathrm{H}, \mathrm{H}_{\text {phenyl }}\right), 7.69$ (dd, $1 \mathrm{H}$, $\left.\mathrm{J}=8.12,1.30 \mathrm{~Hz}, \mathrm{H}_{\text {naphthyl }}\right), 7.65$ (dd, $\left.1 \mathrm{H}, \mathrm{J}=8.34,1.33 \mathrm{~Hz}, \mathrm{H}_{\text {naphthyl }}\right), 7.51-7.48$ (m, $\left.1 \mathrm{H}, \mathrm{H}_{\text {phenyl }}\right)$, 7.39 (dd, $\left.1 \mathrm{H}, \mathrm{J}=8.22,6.93 \mathrm{~Hz}, \mathrm{H}_{\text {naphthyl }}\right), 7.24$ (dd, $1 \mathrm{H}, \mathrm{J}=8.44,6.75 \mathrm{~Hz}, \mathrm{H}_{\text {naphthyl) }}$, 7.01-6.98 (m, $\left.2 \mathrm{H}, \mathrm{H}_{\text {phenyl }}\right), 6.72-6.68$ (m, $\left.1 \mathrm{H}, \mathrm{H}_{\text {phenyl }}\right), 6.64$ (dd, $\left.1 \mathrm{H}, \mathrm{J}=7.04,1.34 \mathrm{~Hz}, \mathrm{H}_{\text {naphthyl }}\right), 5.34$ (d, 1H, $\left.\mathrm{J}=3.15 \mathrm{~Hz}, \mathrm{H}_{\text {dimethoxybenzene }}\right), 2.53$ (dd, $\left.1 \mathrm{H}, \mathrm{J}=8.75,3.14 \mathrm{~Hz}, \mathrm{H}_{\text {dimethoxybenzene }}\right), 2.32$ (d, $1 \mathrm{H}, \mathrm{J}=8.83$ $\left.\mathrm{Hz}, \mathrm{H}_{\text {dimethoxybenzene }}\right), 2.12$ (s, $\left.3 \mathrm{H}, \mathrm{H}_{\text {methyl }}\right), 1.52$ (s, $\left.3 \mathrm{H}, \mathrm{H}_{\text {methyl }}\right) .{ }^{13} \mathrm{C} \mathrm{NMR}\left(500 \mathrm{MHz}, \mathrm{CDCl}_{3}\right): \delta$ $151.14,150.24,150.07,149.96,149.91,149.86,149.78,149.08,148.84,148.60,147.16,146.79$, $142.96,142.80,140.47,136.23,135.75,135.04,134.96,134.50,134.43,134.19,133.42,133.23$, 
$132.40,132.00,131.73,131.55,131.51,131.47,131.26,130.92,130.06,129.79,128.68,128.20$, $127.51,127.44,127.40,127.27,126.67,126.55,126.43,126.37,125.12,124.25,123.99,123.91$, $122.11,121.17,120.66,120.61,120.47,118.97,105.14,104.76,53.26,52.34$. Vis (THF) $\left[\lambda_{\max }\right.$ (nm), (log $\left.\varepsilon\left(\mathrm{M}^{-1} \mathrm{~cm}^{-1}\right)\right]: 427$ (5.26), 525 (3.46), 563 (4.18), 601 (3.54). HRMS (ESI+) m/z: 938.2348 (calcd for $\mathrm{C}_{62} \mathrm{H}_{42} \mathrm{~N}_{4} \mathrm{O}_{2} \mathrm{Zn}(\mathrm{M}+)$ 938.2631). 1ß-ZnB-M: ${ }^{1} \mathrm{H}$ NMR (500 MHz, $\mathrm{CDCl}_{3}$ ): $\delta 8.94\left(\mathrm{~s}, 2 \mathrm{H}, \mathrm{H}_{\beta}\right), 8.92\left(\mathrm{~d}, 1 \mathrm{H}, \mathrm{J}=4.54 \mathrm{~Hz}, \mathrm{H}_{\beta}\right), 8.90\left(\mathrm{~d}, 1 \mathrm{H}, \mathrm{J}=4.55 \mathrm{~Hz}, \mathrm{H}_{\beta}\right), 8.73(\mathrm{~d}, 1 \mathrm{H}$, $\left.\mathrm{J}=4.69 \mathrm{~Hz}, \mathrm{H}_{\beta}\right), 8.45\left(\mathrm{~s}, 1 \mathrm{H}, \mathrm{H}_{\beta}\right), 8.43\left(\mathrm{~d}, 1 \mathrm{H}, \mathrm{J}=4.69 \mathrm{~Hz}, \mathrm{H}_{\beta}\right), 8.40-8.35\left(\mathrm{~m}, 1 \mathrm{H}, \mathrm{H}_{\text {phenyl }}\right), 8.35-$ 8.27 (m, 2 H, $\left.\mathrm{H}_{\text {phenyl }}\right), 8.24$ (d, $\left.1 \mathrm{H}, \mathrm{J}=7.36 \mathrm{~Hz}, \mathrm{H}_{\text {phenyl }}\right), 8.20-8.15$ (m, $\left.1 \mathrm{H}, \mathrm{H}_{\text {phenyl }}\right), 8.11$ (d, $1 \mathrm{H}$, $\left.\mathrm{J}=7.44 \mathrm{~Hz}, \mathrm{H}_{\text {phenyl }}\right), 7.98\left(\mathrm{dd}, 1 \mathrm{H}, \mathrm{J}=6.84,1.31 \mathrm{~Hz}, \mathrm{H}_{\text {naphthyl }}\right), 7.80-7.65\left(\mathrm{~m}, 10 \mathrm{H}, \mathrm{H}_{\text {phenyl }}\right), 7.62$ (dd, $\left.1 \mathrm{H}, \mathrm{J}=8.37,1.31 \mathrm{~Hz}, \mathrm{H}_{\text {naphthyl }}\right), 7.56-7.53$ (m, $\left.1 \mathrm{H}, \mathrm{H}_{\text {phenyl }}\right), 7.42$ (dd, $1 \mathrm{H}, \mathrm{J}=8.28,6.88 \mathrm{~Hz}$, $\left.\mathrm{H}_{\text {naphthyl }}\right), 7.26$ (dd, $\left.1 \mathrm{H}, \mathrm{J}=8.15,6.90 \mathrm{~Hz}, \mathrm{H}_{\text {naphthyl }}\right), 7.18$ (d, $\left.1 \mathrm{H}, \mathrm{J}=7.60 \mathrm{~Hz}, \mathrm{H}_{\text {phenyl }}\right), 7.02-6.96$ (m, 2 H, $\left.\mathrm{H}_{\text {phenyl }}\right), 6.73-6.69$ (m, $\left.1 \mathrm{H}, \mathrm{H}_{\text {phenyl }}\right), 6.48$ (dd, $\left.1 \mathrm{H}, \mathrm{J}=6.80,1.25 \mathrm{~Hz}, \mathrm{H}_{\text {naphthyl }}\right), 5.19$ (d, $1 \mathrm{H}, \mathrm{J}=8.80 \mathrm{~Hz}, \mathrm{H}_{\text {dimethoxybenzene) }}, 3.65$ (d, $1 \mathrm{H}, \mathrm{J}=3.10 \mathrm{~Hz}, \mathrm{H}_{\text {dimethoxybenzene) }}$ ) 3.36 (dd, $1 \mathrm{H}, \mathrm{J}=8.75$, $3.10 \mathrm{~Hz}, \mathrm{H}_{\text {dimethoxybenzene }}$ ), 3.00 (s, $\left.3 \mathrm{H}, \mathrm{H}_{\text {methyl }}\right),-0.15$ (s, $\left.3 \mathrm{H}, \mathrm{H}_{\text {methyl }}\right) .{ }^{13} \mathrm{C} \mathrm{NMR}(500 \mathrm{MHz}$, $\left.\mathrm{CDCl}_{3}\right): \delta 151.34,150.50,150.05,149.99,149.96,149.68,148.62,149.08,147.29,145.98$, $147.16,143.25,143.07,140.22,136.38,135.96,135.56,135.37,134.87,134.58,134.50,134.26$, $133.83,132.68,132.45,132.27,131.60,131.57,131.46,131.12,131.06,130.04,128.77,128.65$, $128.45,127.38,127.31,127.25,126.90,126.62,126.51,126.42,126.40,126.36,126.04,125.38$, $124.59,124.39,123.76,121.87,120.92,120.55,120.15,114.95,108.67,107.25,54.95,51.91$. Vis (THF) $\left[\lambda_{\max }(\mathrm{nm}),\left(\log \varepsilon\left(\mathrm{M}^{-1} \mathrm{~cm}^{-1}\right)\right]: 427\right.$ (5.45), 525 (3.41), 563 (4.24), 601 (3.58). HRMS (ESI+) m/z: 938.2643 (calcd for $\mathrm{C}_{62} \mathrm{H}_{42} \mathrm{~N}_{4} \mathrm{O}_{2} \mathrm{Zn}(\mathrm{M}+)$ 938.2631). 


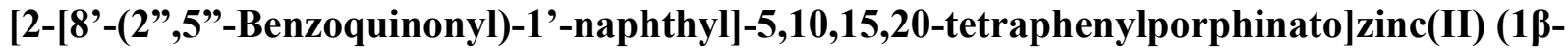

Zn). A solution of $\mathbf{1 \beta}-\mathbf{Z n A}-\mathbf{M}(40 \mathrm{mg}, 42.5 \mu \mathrm{mol})$ in toluene $(10 \mathrm{ml})$ was cooled to $-78{ }^{\circ} \mathrm{C}$, following which ten equivalents of $\mathrm{BBr}_{3}\left(0.43 \mathrm{~mL}\right.$ of $1.0 \mathrm{M} \mathrm{CH}_{2} \mathrm{Cl}_{2}$ solution, $\left.0.43 \mathrm{mmol}\right)$ were added dropwise. The reaction was stirred for $1 \mathrm{~h}$ at $-78^{\circ} \mathrm{C}$, and then slowly warmed to room temperature. After stirring for an additional $12 \mathrm{~h}$, a small quantity of methanol $(1 \mathrm{ml})$ was added; the mixture was stirred for 15 min, partitioned between $\mathrm{CH}_{2} \mathrm{Cl}_{2}$ and aq. $\mathrm{Na}_{2} \mathrm{CO}_{3}$, washed with aq. $\mathrm{Na}_{2} \mathrm{CO}_{3}(3 \times 20 \mathrm{~mL})$, dried, and filtered. $\mathrm{PbO}_{2}(40 \mathrm{mg}, 0.18 \mathrm{mmol})$ was added, and the heterogeneous $\mathrm{CH}_{2} \mathrm{Cl}_{2}$ solution was stirred for $1 \mathrm{~h}$. After filtration and removal of the volatiles, the brown material was dissolved in $\mathrm{CHCl}_{3}$. A methanol solution of $\mathrm{Zn}(\mathrm{OAc})_{2} \cdot 2 \mathrm{H}_{2} \mathrm{O}(44 \mathrm{mg}$, $0.2 \mathrm{mmol}$ in $1.5 \mathrm{ml}$ of $\mathrm{MeOH})$ was added to a $\mathrm{CHCl}_{3}$ solution of [2-[8'-(2",5"-benzoquinonyl)1 '-naphthyl]-5,10,15,20-tetraphenylporphirin. The reaction mixture was heated at $40{ }^{\circ} \mathrm{C}$ for $3 \mathrm{~h}$. Following the addition of pyridine $(1 \mathrm{ml})$ and the removal of volatiles, the recovered purple residue was chromatographed on silica gel (9:1 hexanes:THF). 1ß-Zn was isolated as a purple solid; isolated yield $=32.4 \mathrm{mg}(84 \%$, based on $40 \mathrm{mg}$ of compound $\mathbf{1 \beta}-\mathbf{Z n A}-\mathbf{M}){ }^{1} \mathrm{H}$ NMR $(500$ $\mathrm{MHz}, \mathrm{CD}_{2} \mathrm{Cl}_{2}, \mathbf{1 \beta - Z n A : ~} \mathbf{1 \beta - Z n B}=1: 4$, peaks only for a $\mathbf{1 \beta - Z n B}$ are listed): $\delta 8.97\left(\mathrm{~s}, 1 \mathrm{H}, \mathrm{H}_{\beta}\right)$, $8.96\left(\mathrm{~s}, 1 \mathrm{H}, \mathrm{H}_{\beta}\right), 8.95$ (d, $\left.1 \mathrm{H}, \mathrm{J}=4.72 \mathrm{~Hz}, \mathrm{H}_{\beta}\right), 8.92$ (d, $\left.1 \mathrm{H}, \mathrm{J}=4.78 \mathrm{~Hz}, \mathrm{H}_{\beta}\right), 8.77$ (d, $1 \mathrm{H}, \mathrm{J}=4.71$ $\left.\mathrm{Hz}, \mathrm{H}_{\beta}\right), 8.69\left(\mathrm{~s}, 1 \mathrm{H}, \mathrm{H}_{\beta}\right), 8.46\left(\mathrm{~d}, 1 \mathrm{H}, \mathrm{J}=4.70 \mathrm{~Hz}, \mathrm{H}_{\beta}\right), 8.40-8.30\left(\mathrm{~m}, 3 \mathrm{H}, \mathrm{H}_{\text {phenyl }}\right), 8.18$ (d, $1 \mathrm{H}$, $\left.\mathrm{J}=8.01 \mathrm{~Hz}, \mathrm{H}_{\text {phenyl }}\right), 8.16-8.11\left(\mathrm{~m}, 1 \mathrm{H}, \mathrm{H}_{\text {phenyl }}\right), 8.08$ (d, $\left.1 \mathrm{H}, \mathrm{J}=8.04 \mathrm{~Hz}, \mathrm{H}_{\text {phenyl }}\right), 8.00$ (dd, $1 \mathrm{H}$, $\left.\mathrm{J}=6.87,1.36 \mathrm{~Hz}, \mathrm{H}_{\text {naphthyl }}\right), 7.90-7.75$ (m, $\left.7 \mathrm{H}, \mathrm{H}_{\text {phenyl }}\right), 7.82\left(\mathrm{dd}, 1 \mathrm{H}, \mathrm{J}=8.24,1.24 \mathrm{~Hz}, \mathrm{H}_{\text {naphthyl }}\right)$, 7.75-7.70 (m, $\left.1 \mathrm{H}, \mathrm{H}_{\text {phenyl }}\right), 7.71$ (dd, $\left.1 \mathrm{H}, \mathrm{J}=8.36,1.31 \mathrm{~Hz}, \mathrm{H}_{\text {naphthyl }}\right), 7.54$ (dd, $1 \mathrm{H}, \mathrm{J}=8.32,6.90$ Hz, $\left.\mathrm{H}_{\text {naphthyl }}\right), 7.40$ (d, $\left.1 \mathrm{H}, \mathrm{J}=7.30 \mathrm{~Hz}, \mathrm{H}_{\text {phenyl }}\right), 7.36$ (dd, $\left.1 \mathrm{H}, \mathrm{J}=8.33,6.86 \mathrm{~Hz}, \mathrm{H}_{\text {naphthyl }}\right), 7.25$ (d, $\left.1 \mathrm{H}, \mathrm{J}=7.45 \mathrm{~Hz}, \mathrm{H}_{\text {phenyl }}\right), 6.98-6.93$ (m, 2 H, H $\mathrm{H}_{\text {phenyl }}$ ), 6.90 (td, $\left.1 \mathrm{H}, \mathrm{J}=7.46,1.42 \mathrm{~Hz}, \mathrm{H}_{\text {phenyl }}\right), 6.70$ (td, $\left.1 \mathrm{H}, \mathrm{J}=7.39,1.35 \mathrm{~Hz}, \mathrm{H}_{\text {phenyl }}\right), 6.62$ (dd, $\left.1 \mathrm{H}, \mathrm{J}=6.80,1.32 \mathrm{~Hz}, \mathrm{H}_{\text {naphthyl }}\right), 5.69$ (d, $1 \mathrm{H}, \mathrm{J}=9.88$ 
Hz, Hbenzoquinone), 4.07 (d, $\left.1 \mathrm{H}, \mathrm{J}=2.60 \mathrm{~Hz}, \mathrm{H}_{\text {benzoquinone }}\right), 3.60$ (dd, $1 \mathrm{H}, \mathrm{J}=9.95,2.60 \mathrm{~Hz}$, $\mathrm{H}_{\text {benzoquinone). }}\left(500 \mathrm{MHz}, \mathrm{C}_{6} \mathrm{D}_{6}, \mathbf{1 \beta - Z n A}: \mathbf{1 \beta}-\mathbf{Z n B}=1.2: 1\right): \delta 9.03\left(\mathrm{~d}_{\mathrm{A}}, 1 \mathrm{H}, \mathrm{J}=4.52 \mathrm{~Hz}, \mathrm{H}_{\beta}\right), 9.01$ $\left(\mathrm{d}_{\mathrm{B}}, 1 \mathrm{H}, \mathrm{J}=4.56 \mathrm{~Hz}, \mathrm{H}_{\beta}\right), 8.97\left(\mathrm{~d}_{\mathrm{A}}, 1 \mathrm{H}, \mathrm{J}=4.50 \mathrm{~Hz}, \mathrm{H}_{\beta}\right), 8.96\left(\mathrm{~d}_{\mathrm{B}}, 1 \mathrm{H}, \mathrm{J}=4.56 \mathrm{~Hz}, \mathrm{H}_{\beta}\right), 8.92\left(\mathrm{~s}_{\mathrm{B}}, 1\right.$ $\left.\mathrm{H}, \mathrm{H}_{\beta}\right), 8.91\left(\mathrm{~s}_{\mathrm{B}}, 1 \mathrm{H}, \mathrm{H}_{\beta}\right), 8.89\left(\mathrm{~s}_{\mathrm{A}}, 1 \mathrm{H}, \mathrm{H}_{\beta}\right), 8.81\left(\mathrm{~s}_{\mathrm{B}}, 1 \mathrm{H}, \mathrm{H}_{\beta}\right), 8.80\left(\mathrm{~d}_{\mathrm{B}}, 1 \mathrm{H}, \mathrm{J}=4.77 \mathrm{~Hz}, \mathrm{H}_{\beta}\right)$, $8.78\left(\mathrm{~d}_{\mathrm{A}}, 1 \mathrm{H}, \mathrm{J}=4.58 \mathrm{~Hz}, \mathrm{H}_{\beta}\right), 8.78\left(\mathrm{~s}_{\mathrm{A}}, 1 \mathrm{H}, \mathrm{H}_{\beta}\right), 8.73\left(\mathrm{~d}_{\mathrm{A}}, 1 \mathrm{H}, \mathrm{J}=4.73 \mathrm{~Hz}, \mathrm{H}_{\beta}\right), 8.55\left(\mathrm{~d}_{\mathrm{B}}, 1 \mathrm{H}\right.$, $\left.\mathrm{J}=4.64 \mathrm{~Hz}, \mathrm{H}_{\beta}\right), 8.19-8.16\left(\mathrm{~m}, 1 \mathrm{H}, \mathrm{H}_{\text {phenyl }}\right), 8.12-8.04$ (m, $\left.8 \mathrm{H}, \mathrm{H}_{\text {phenyl }}\right), 8.00-7.98$ (m, $1 \mathrm{H}$, $\left.\mathrm{H}_{\text {phenyl }}\right)$, 7.97-7.95 (m, $\left.2 \mathrm{H}, \mathrm{H}_{\text {phenyl }}\right), 7.77$ ( $\left.\mathrm{dd}_{\mathrm{A}}, 1 \mathrm{H}, \mathrm{J}=6.85,1.41 \mathrm{~Hz}, \mathrm{H}_{\text {naphthyl }}\right), 7.71$ (dd $\mathrm{B}, 1 \mathrm{H}$, $\left.\mathrm{J}=6.87,1.29 \mathrm{~Hz}, \mathrm{H}_{\text {naphthyl }}\right), 7.44-7.32\left(\mathrm{~m}, 16 \mathrm{H}, \mathrm{H}_{\text {phenyl }}\right), 7.38\left(\mathrm{dd}_{\mathrm{A}}, 1 \mathrm{H}, \mathrm{J}=8.10,1.28 \mathrm{~Hz}\right.$, $\left.\mathrm{H}_{\text {naphthyl }}\right), 7.37$ (dd $\left.\mathrm{B}, 1 \mathrm{H}, \mathrm{J}=8.25,1.15 \mathrm{~Hz}, \mathrm{H}_{\text {naphthyl }}\right), 7.34\left(\mathrm{dd}_{\mathrm{A}}, 1 \mathrm{H}, \mathrm{J}=8.41,1.38 \mathrm{~Hz}, \mathrm{H}_{\text {naphthyl }}\right)$, $7.30\left(\mathrm{dd}_{\mathrm{B}}, 1 \mathrm{H}, \mathrm{J}=8.38,1.27 \mathrm{~Hz}, \mathrm{H}_{\text {naphthyl }}\right), 7.14\left(\mathrm{dd}_{\mathrm{A}}, 1 \mathrm{H}, \mathrm{J}=8.26,6.97 \mathrm{~Hz}, \mathrm{H}_{\text {naphthyl }}\right), 7.08$ (dd, 1 $\left.\mathrm{H}, \mathrm{J}=8.27,6.86 \mathrm{~Hz}, \mathrm{H}_{\text {naphthyl }}\right)$, 7.08-7.06 (m, $\left.1 \mathrm{H}, \mathrm{H}_{\text {phenyl }}\right), 7.05$ (bs, $\left.1 \mathrm{H}, \mathrm{H}_{\text {phenyl }}\right), 6.96$ (bs, $2 \mathrm{H}$, $\left.\mathrm{H}_{\text {phenyl }}\right), 6.92\left(\mathrm{dd}_{\mathrm{A}}, 1 \mathrm{H}, \mathrm{J}=8.14,7.08 \mathrm{~Hz}, \mathrm{H}_{\text {naphthyl }}\right), 6.86\left(\mathrm{dd}_{\mathrm{B}}, 1 \mathrm{H}, \mathrm{J}=8.26,6.82 \mathrm{~Hz}, \mathrm{H}_{\text {naphthyl }}\right)$, 6.77-6.69 (m, 4 H, $\left.\mathrm{H}_{\text {phenyl }}\right)$, 6.68-6.60 (m, 3 H, $\left.\mathrm{H}_{\text {phenyl }}\right), 6.49-6.46$ (m, $\left.1 \mathrm{H}, \mathrm{H}_{\text {phenyl }}\right), 6.32$ ( $\mathrm{dd}_{\mathrm{A}}, 1$ $\left.\mathrm{H}, \mathrm{J}=7.03,1.30 \mathrm{~Hz}, \mathrm{H}_{\text {naphthyl }}\right), 6.03\left(\mathrm{dd}_{\mathrm{B}}, 1 \mathrm{H}, \mathrm{J}=6.82,1.28 \mathrm{~Hz}, \mathrm{H}_{\text {naphthyl }}\right), 5.09\left(\mathrm{~d}_{\mathrm{B}}, 1 \mathrm{H}, \mathrm{J}=10.0\right.$ $\left.\mathrm{Hz}, \mathrm{H}_{\text {benzoquinone }}\right), 4.79$ ( $\left.\mathrm{d}_{\mathrm{B}}, 1 \mathrm{H}, \mathrm{J}=2.60 \mathrm{~Hz}, \mathrm{H}_{\text {benzoquinone }}\right), 3.55\left(\mathrm{~d}_{\mathrm{A}}, 1 \mathrm{H}, \mathrm{J}=2.59 \mathrm{~Hz}, \mathrm{H}_{\text {benzoquinone }}\right)$, $2.93\left(\mathrm{dd}_{\mathrm{B}}, 1 \mathrm{H}, \mathrm{J}=9.97,2.59 \mathrm{~Hz}, \mathrm{H}_{\text {benzoquinone }}\right), 1.90\left(\mathrm{dd}_{\mathrm{A}}, 1 \mathrm{H}, \mathrm{J}=10.0,2.60 \mathrm{~Hz}, \mathrm{H}_{\text {benzoquinone }}\right), 1.68$ $\left(\mathrm{d}_{\mathrm{A}}, 1 \mathrm{H}, \mathrm{J}=9.84 \mathrm{~Hz}, \mathrm{H}_{\text {benzoquinone }}\right) . \quad$ Vis $\left(\mathrm{CH}_{2} \mathrm{Cl}_{2},>95 \% \mathrm{~B}\right.$ form $)\left[\lambda_{\max }(\mathrm{nm}),\left(\log \varepsilon\left(\mathrm{M}^{-1} \mathrm{~cm}^{-1}\right)\right]: 427\right.$ (5.40), 519 (3.63), 555 (4.10), 597 (3.47). (THF, A:B=3:2): 428 (5.41), 515 (3.92), 562 (4.06). HRMS (ESI+) m/z: 909.2353(calcd for $\mathrm{C}_{60} \mathrm{H}_{36} \mathrm{~N}_{4} \mathrm{O}_{2} \mathrm{Zn}(\mathrm{MH}+)$ 909.2208). 
<smiles>[B]OC(C)(C)C(C)(C)O[B]</smiles>

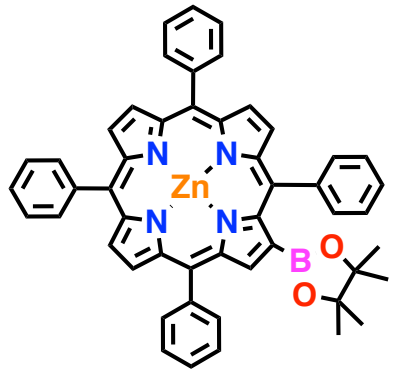

TPPZnB

Scheme S1. Synthesis of [2-(4',4',5',5'-tetramethyl[1',3',2']dioxaborolan-2'-yl)-5,10,15,20tetraphenylporphinato]zinc(II) (TPPZnB).<smiles>COc1ccc(OC)c(-c2c(I)ccc3cccc(OC)c23)c1</smiles>
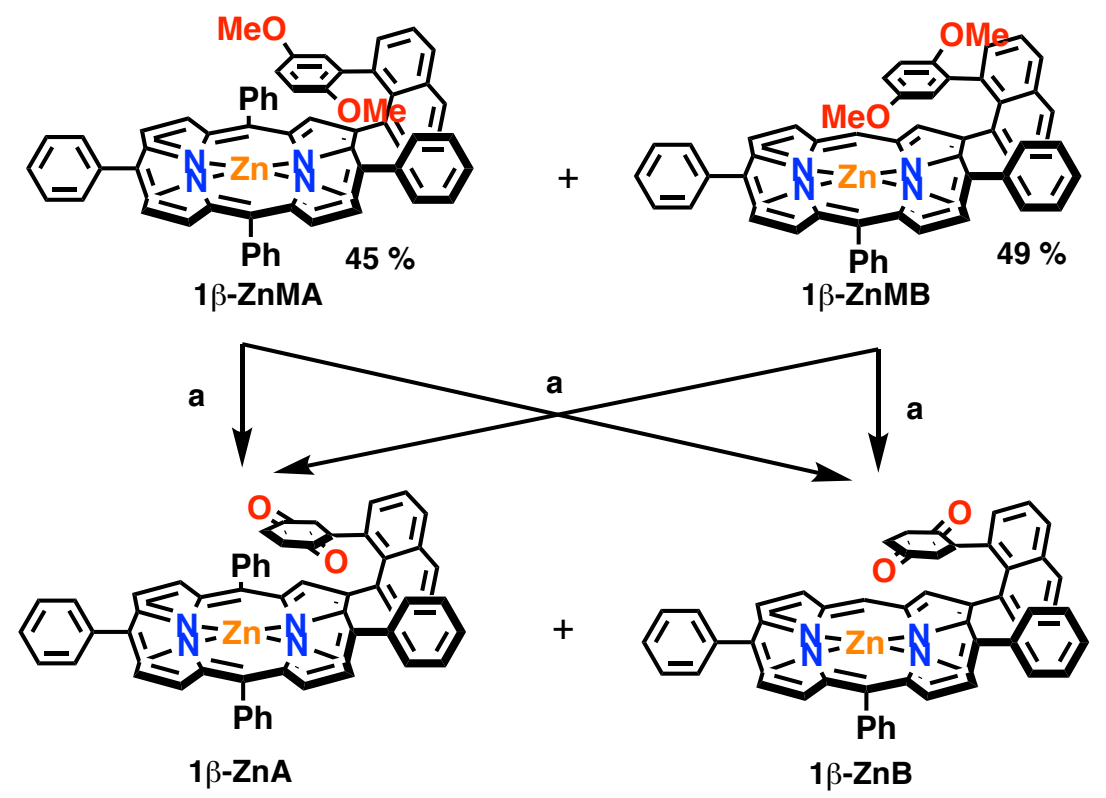

a: (1) $\mathrm{BBr}_{3}$, toulene, $-78{ }^{\circ} \mathrm{C} \sim \mathrm{rt}$, (2) $\mathrm{PbO}_{2}, \mathrm{CH}_{2} \mathrm{Cl}_{2}$, (3) $\mathrm{Zn}(\mathrm{OAc})_{2}, \mathrm{CHCl}_{3} / \mathrm{MeOH}$

Scheme S2. Synthesis of [2-[8'-(2",5"-dimethoxyphenyl)-1'-naphthyl]-5,10,15,20tetraphenylporphinato]zinc(II) (1/ -ZnM) and [2-[8'-(2",5"-benzoquinonyl)-1'-naphthyl]5,10,15,20-tetraphenylporphinato]zinc(II) $(\mathbf{1 \beta - Z n})$. 
Analysis of Electronic Absorption Spectra. The visible absorption spectra of 1a-Zn,

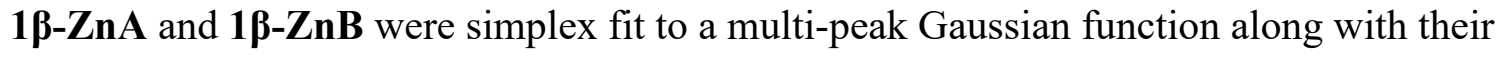
dimethoxyphenyl analogues. The Q-state region of 1及-ZnMA, for example, can be fit by three Gaussian functions having identical spectral width $\left(837 \mathrm{~cm}^{-1}, \mathrm{FWHM}\right)$. Deconvolution of the of 1a-Zn, $1 \boldsymbol{\beta}-\mathbf{Z n A}$, and $\mathbf{1 \beta}-\mathrm{ZnB}$ spectra requires at a minimum three Gaussian functions having different spectral widths to fit the absorption envelopes. The fit parameters of CT band and Q band are listed in Table S1 and Table S2. 


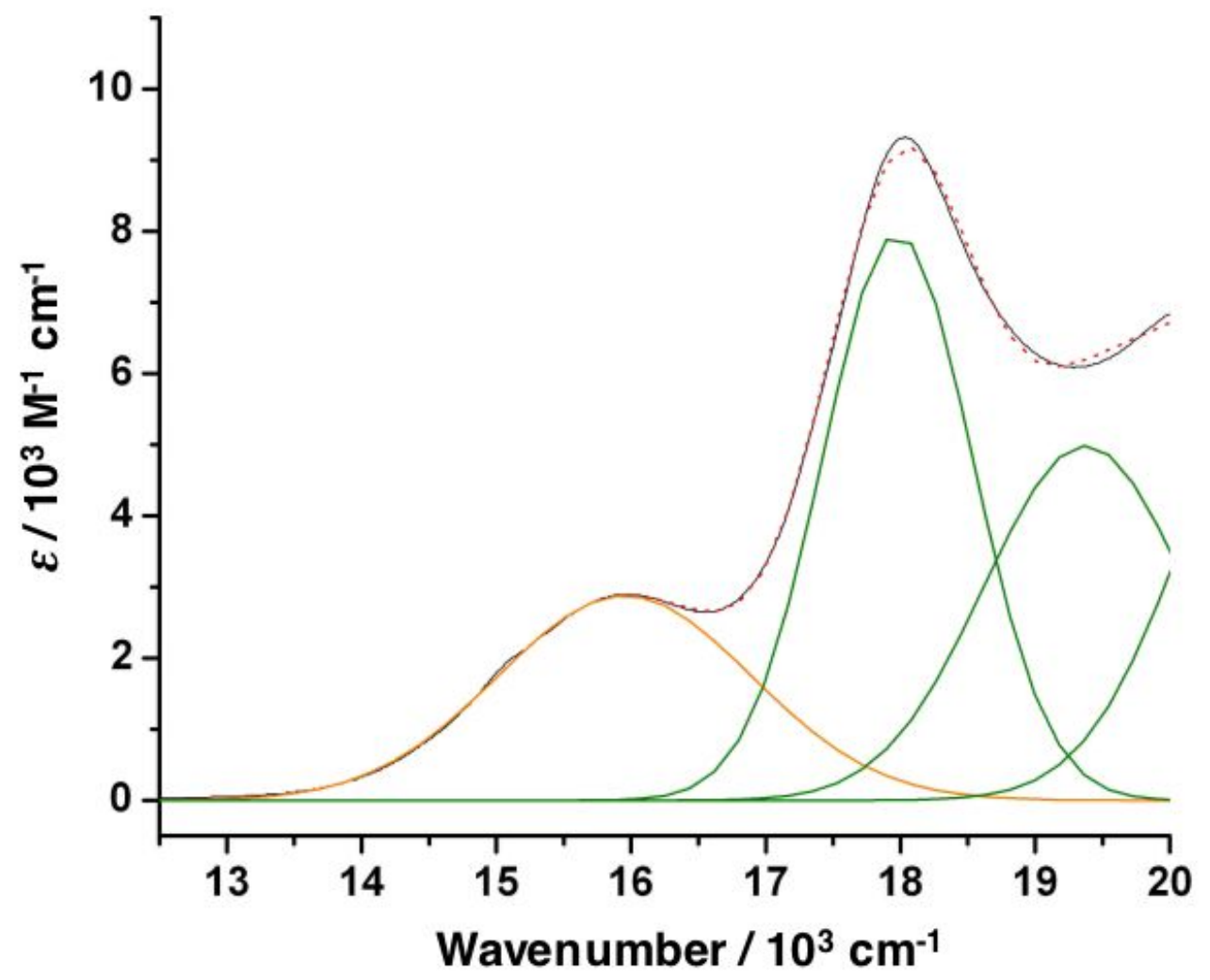

Figure S1. Steady-state absorption spectra recorded for: 1a-Zn in 10:1 hexanes:THF solvent. Spectral fitting using a multi-peak Gaussian function for $\mathbf{1 a - Z n}$ is shown by orange (CT band) and green (Q bands) lines. 


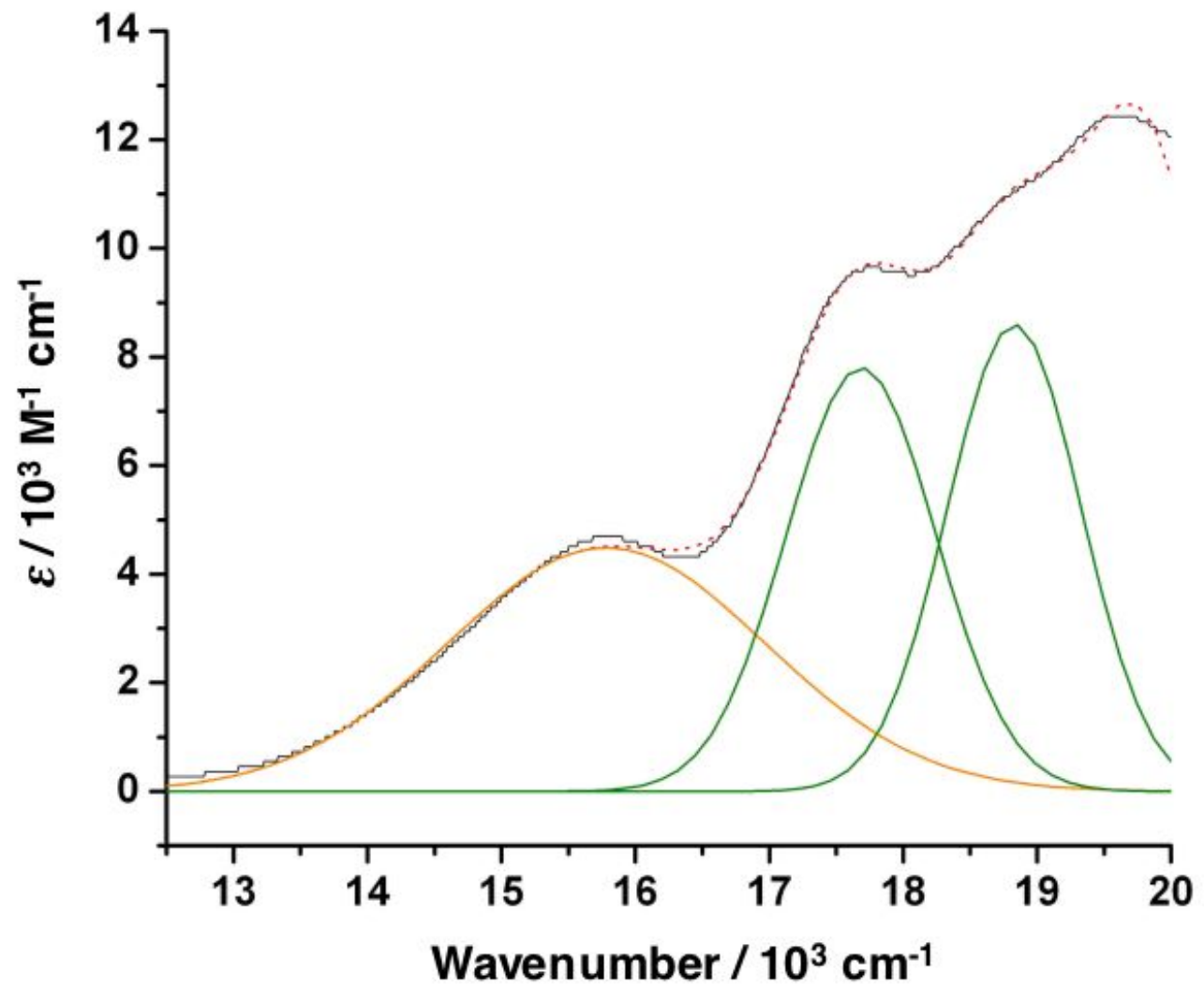

Figure S2. Steady-state absorption spectra recorded for: $\mathbf{1 \beta - Z n A}$ in 10:1 hexanes:THF solvent. Spectral fitting using a multi-peak Gaussian function for $\mathbf{1 \beta - Z n A}$ is shown by orange (CT band) and green (Q bands) lines. 


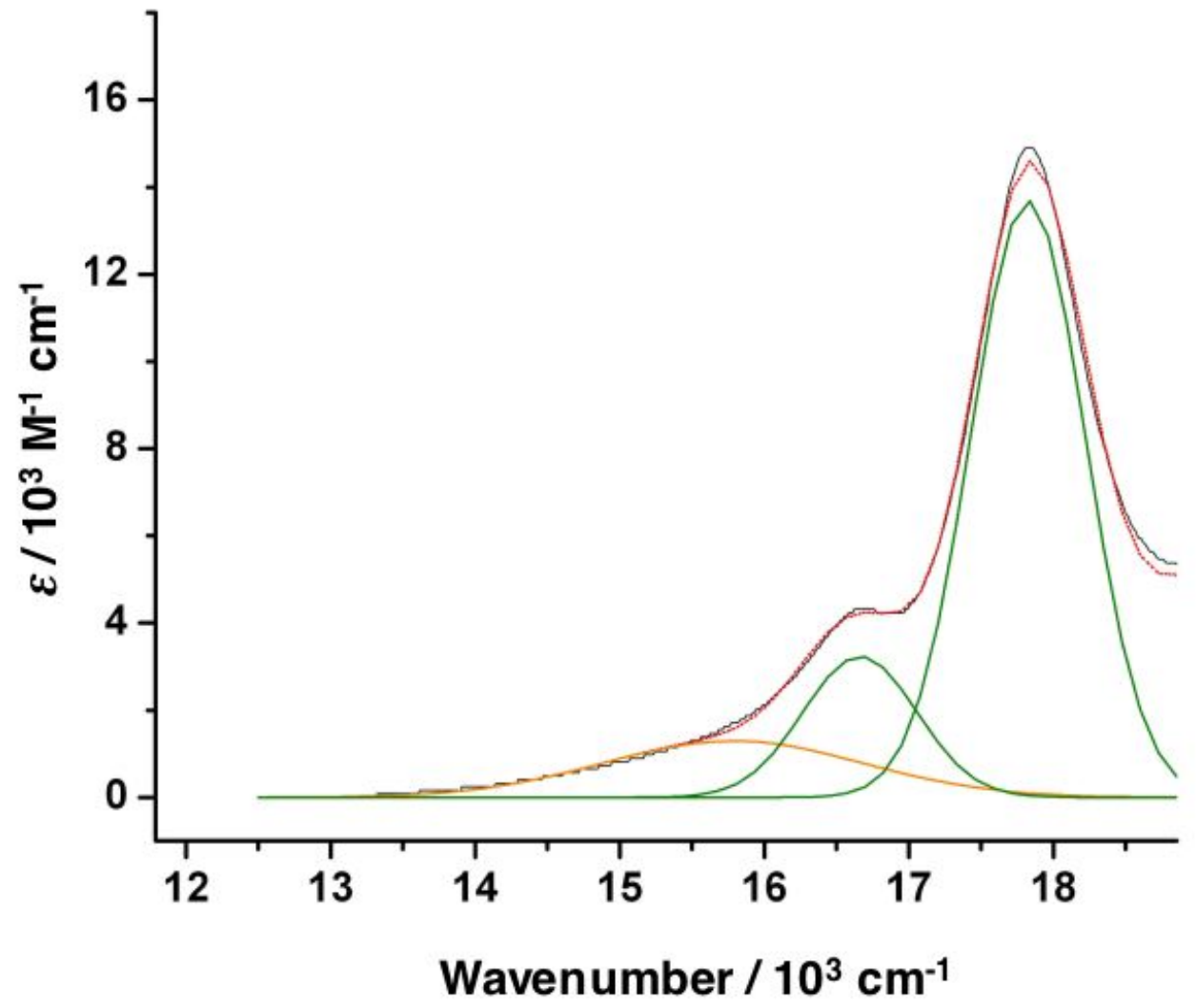

Figure S3. Steady-state absorption spectra recorded for: $\mathbf{1 \beta - Z n B}$ in 10:1 hexanes:THF solvent. Spectral fitting using a multi-peak Gaussian function for $\mathbf{1 \beta - Z n B}$ is shown by orange (CT band) and green (Q bands) lines. 
Table S1. Fit parameters determined by the deconvolution and Hush analysis of CT bands

\begin{tabular}{ccrccc}
\hline Compound & $\begin{array}{c}R_{D A}{ }^{a} \\
\AA\end{array}$ & $\begin{array}{c}\varepsilon_{\max } \\
\mathrm{M}^{-1} \mathrm{~cm}^{-1}\end{array}$ & $\begin{array}{c}v_{\max } \\
\mathrm{cm}^{-1}\end{array}$ & $\begin{array}{c}v_{F W H M} \\
\mathrm{~cm}^{-1}\end{array}$ & $\begin{array}{c}H_{D A} \\
\mathrm{~cm}^{-1}\end{array}$ \\
\hline $\mathbf{1 \beta - Z n A}$ & 3.57 & $4489 \pm 27$ & 15784 & $2798 \pm 9$ & $2569 \pm 12$ \\
$\mathbf{1 \beta - Z n B}$ & 3.45 & $957 \pm 19$ & 15784 & $2805 \pm 22$ & $1229 \pm 7$ \\
$\mathbf{1 a - Z n}$ & 3.37 & $2876 \pm 13$ & 15952 & $2221 \pm 5$ & $1951 \pm 7$ \\
\hline
\end{tabular}

${ }^{a}$ The porphyrin plane-to-quinonyl centroid distances for DFT optimized structures. ${ }^{8}$

Table S2. Electronic couplings determined for charge separation reactions estimated by Q $(1,0)$ band line broadening.

\begin{tabular}{ccccccccc}
\hline \multirow{2}{*}{ Compound } & $\begin{array}{c}R_{D A} \\
\AA\end{array}$ & $\begin{array}{c}v_{F W H M}{ }^{b} \\
\mathrm{~cm}^{-1}\end{array}$ & $\begin{array}{c}v_{F W H M}{ }^{c} \\
\mathrm{~cm}^{-1}\end{array}$ & $\begin{array}{c}\Delta v_{F W H M} \\
\mathrm{~cm}^{-1}\end{array}$ & $\begin{array}{c}\tau_{C S^{d}} \\
\mathrm{fs}\end{array}$ & $\begin{array}{c}\lambda S^{e} \\
\mathrm{eV}\end{array}$ & $\begin{array}{c}\Delta G_{\max }{ }^{f} \\
\mathrm{eV}\end{array}$ & $\begin{array}{c}H_{D A^{g}} \\
\mathrm{~cm}^{-1}\end{array}$ \\
\hline $\mathbf{1 \beta - Z n A}$ & 3.57 & $1314 \pm 4$ & $837 \pm 3$ & $477 \pm 7$ & $5.56 \pm 0.08$ & 0.12 & -1.24 & $1977 \pm 13$ \\
$\mathbf{1 \beta - Z n B}$ & 3.45 & $933 \pm 5$ & $837 \pm 3$ & $96 \pm 8$ & $27.6 \pm 2.1$ & 0.12 & -1.24 & $887 \pm 37$ \\
$\mathbf{1 a - Z n}$ & 3.37 & $1310 \pm 3$ & $837 \pm 3$ & $473 \pm 6$ & $5.61 \pm 0.07$ & 0.12 & -1.26 & $2004 \pm 13$ \\
\hline
\end{tabular}

${ }^{a}$ The porphyrin plane-to-quinonyl centroid distances for DFT optimized structures. ${ }^{8}{ }^{b} \mathrm{FWHM}$ of Q $(1,0)$ band of ET systems. ${ }^{c} \mathrm{FWHM}$ of $\mathrm{Q}(1,0)$ band of $\mathbf{1 \beta}-\mathbf{Z n B}$. ${ }^{d}$ By the relation of $\Delta t \Delta E=\mathrm{h} / 2 . \tau_{C S}(\mathrm{fs})=$ $2653 / \Delta v_{\text {FWнм }}\left(\mathrm{cm}^{-1}\right)$. ${ }^{e}$ Solvent reorganization energy calculated using the dielectric continuum model developed by Tachiya. ${ }^{9}$ Overall molecular shape is assumed to be a cylinder with $5.9 \AA$ diameter and $3.5+R_{D A} \AA$ length. Solvent parameters, $\varepsilon_{\infty}$ and $\varepsilon_{s}$, were used with those of $\mathrm{CHCl}_{3} .{ }^{f} \Delta G_{\max }=h c v_{\max }-\left(\lambda_{S}+\right.$ $\left.\lambda_{v}\right)$ where $\lambda_{v}=0.6 \mathrm{eV} .{ }^{g}$ By the Marcus-Levich-Jortner equation. ${ }^{10-12}$

$$
k_{E T}=\frac{2 \pi}{\mathrm{h}} \frac{V_{e l}^{2}}{\sqrt{4 \pi \lambda_{S} k_{B} T}} \exp \left(-S_{c}\right) \sum_{m=0}^{\infty} \frac{S_{c}^{m}}{m !} \exp \left(-\frac{\left(\Delta G+\lambda_{S}+m \mathrm{~h}\langle\omega\rangle\right)^{2}}{4 \lambda_{S} k_{B} T}\right), S_{c}=\frac{\lambda_{i}}{h\langle\omega\rangle}, \mathrm{h}\langle\omega\rangle=1600 \mathrm{~cm}^{-1}
$$


Femtosecond Laser Spectrometer. Transient absorption spectra were obtained via standard pump-probe methods, using a spectrometry system that has previously been described in detail. ${ }^{13}$ In brief, optical pulses $(\geq 120 \mathrm{fs})$ centered at $775 \mathrm{~nm}$, are generated using a Ti:Sapphire laser (Clark-MXR, CPA-2001), which consists of a regenerative amplifier seeded by a mode-locked fiber oscillator. Optical parametric amplifiers (near-IR and visible OPAs, ClarkMXR) generate excitation pulses tunable in wavelength from the UV through the near-IR region. The pump beam, chopped at half the laser repetition rate $(\sim 500 \mathrm{~Hz})$, is passed through an optical delay line. The pump beam intensity is monitored using a silicon photodiode. A fraction of the output from the regenerative amplifier is focused into a $2 \mathrm{~mm}$ c-cut sapphire plate to generate a white light continuum, which is used as the probe beam. The polarization of the pump and probe beams are controlled by a half-wave plate and an appropriate polarizer (probe - thin film, pump Rochor prism). The pump beam is focused into the sample cell with an $\mathrm{f}=40 \mathrm{~cm}$ lens, while the probe beam is focused with an $\mathrm{f}=10 \mathrm{~cm}$ lens. After passing through the sample, the probe light is focused onto the entrance slit of the computer-controlled image spectrometer (SpectraPro-150, Acton Research Corporation). A CCD array detector (Roper Scientific, 1024 x 128 elements), interfaced to the spectrometer, records the spectrum of the probe light from the UV $(\sim 370 \mathrm{~nm})$ to the near-IR $(\sim 1100 \mathrm{~nm})$, providing spectral resolution better than $0.5 \mathrm{~nm}$. To provide shot-byshot detection at a $1 \mathrm{kHz}$ repetition rate, the entrance slit of the image spectrometer is optically masked to shield the upper bins of the CCD. Thirty-two data points are binned for each wavelength, with the resulting spectrum transferred to the computer. Pairs of consecutive spectra are measured with $\left(\mathrm{I}_{\mathrm{on}}(\lambda)\right)$ and without $\left(\mathrm{I}_{\mathrm{off}}(\lambda)\right)$ optical pumping to determine the 
difference spectrum, $\Delta \mathrm{A}=\log \left(\mathrm{I}_{\text {off }}(\lambda) / \mathrm{I}_{\mathrm{on}}(\lambda)\right)$. All transient spectra reported represent averages obtained over 4-6 scans with each scan consisting of 150-250 points.

The delay line utilizes three computer-controlled delay stages. Short time delays are effected with Nanomover stages (Melles Griot), while longer delay times (up to $8.5 \mathrm{~ns}$ ) are achieved using a Compumotor-6000 (Parker). The baseline noise level in these transient absorption experiments corresponds to $\sim 0.1 \mathrm{mOD}$ per second of signal accumulation. The time resolution is probe wavelength dependent; in these experiments, the FWHM of the instrument response function (IRF) varied between $140-200 \mathrm{fs}(e . g$., at $680 \mathrm{~nm}$, the IRF was $150 \pm 6 \mathrm{fs}$ ). The sample pump energy was $\sim 300 \mathrm{~nJ}$; the spot size diameter was $0.3 \mathrm{~mm}$.

Transient optical experiments were performed using degassed sample solutions prepared from dry solvents circulated in a $2 \mathrm{~mm}$ path length Schlenk-style optical cell. For the experiment with $1 \%$ pyridine, sample solvents were prepared in a storage tube by mixing $99 \mathrm{ml}$ of dry solvent with $1 \mathrm{ml}$ of dry pyridine. The concentrations of sample solutions were fixed by adjusting optical density at excitation wavelength $c a 0.5$. All dynamical experiments were carried out at room temperature $\left(23 \pm 1{ }^{\circ} \mathrm{C}\right)$. 

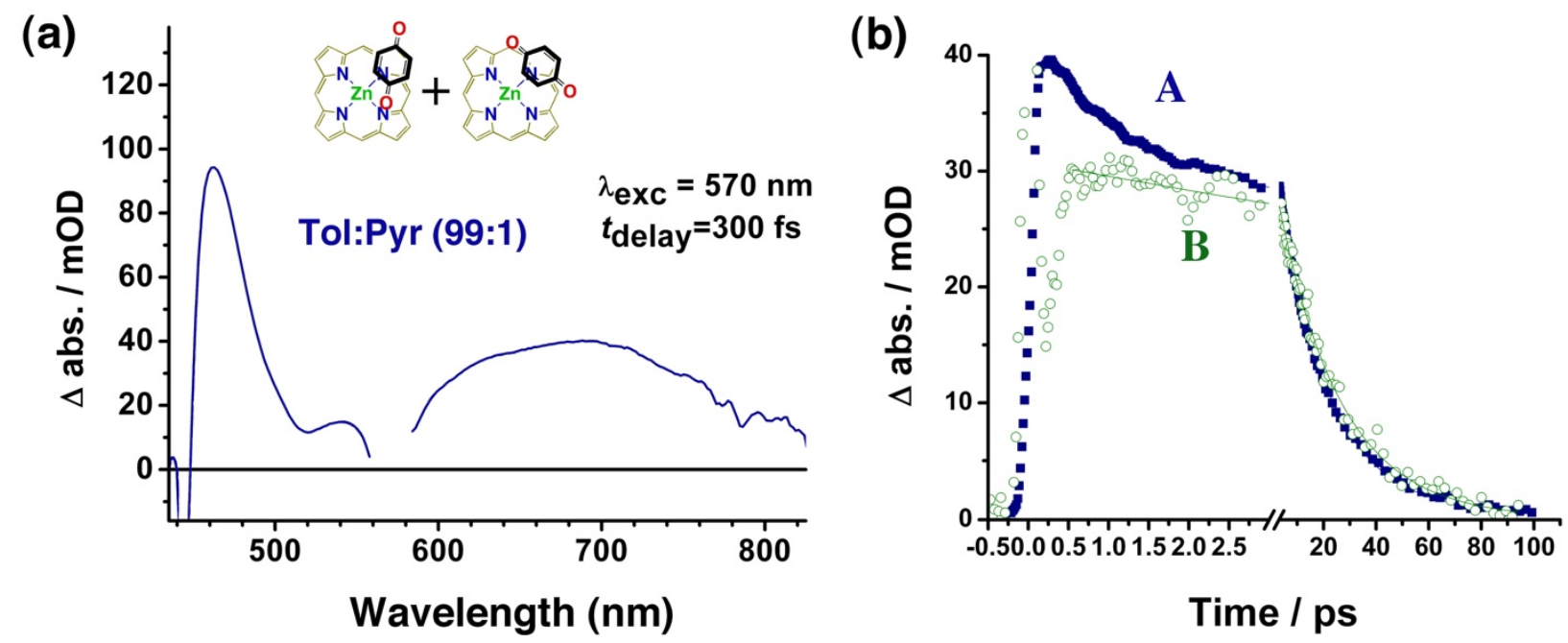

Figure S4. (a) Transient absorption spectra of a $\mathbf{1 \beta}-\mathbf{Z n A} \mathbf{A}+\mathbf{1 \beta}-\mathbf{Z n B}$ equilibrium mixture in toluene (blue). Time delays are shown as insets. Note that the porphyryl phenyl groups have been omitted for clarity (b) Transient decay kinetics determined at $650 \mathrm{~nm}$ for (A) $\mathbf{1 \beta - Z n A}+\mathbf{1 \beta - Z n B}$ in toluene (blue square) (B) $\mathbf{1 a - Z n}$ in toluene (green open circle). The best biexponential fit (convoluted with the IRF) is depicted by the thin line. Experimental conditions: $\lambda_{\mathrm{ex}}=570 \mathrm{~nm}$, temperature $=23 \pm 1^{\circ} \mathrm{C}$. 


\section{Theoretical Analysis}

Tables S3-4 tabulate GMH-derived electronic couplings $\left(\mathrm{H}_{\mathrm{DA}} \mathrm{S}, \mathrm{cm}^{-1}\right)$ and transition dipole moments (TRDMs, Debye) for thermal charge recombination processes determined at the

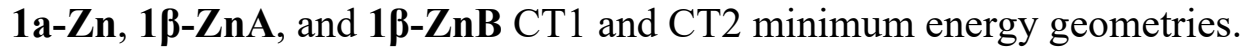

Table S3: GMH-derived electronic couplings $\left(\mathrm{H}_{\mathrm{DAS}}, \mathrm{cm}^{-1}\right)$ and transition dipole moments (TRDMs, Debye) for thermal charge recombination processes determined at the $1 \mathbf{a}-\mathbf{Z n}, \mathbf{1} \boldsymbol{\beta}-\mathbf{Z n A} \mathbf{A}$,

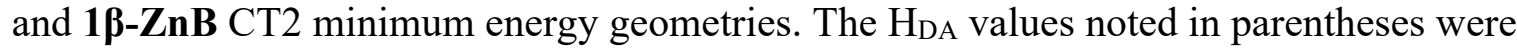
obtained using the same GMH approach but without projecting the transition dipole moments along the charge transfer direction $\left(\mu_{C S}-\mu_{L E}\right)$, where $\mu_{C S}$ and $\mu_{L E}$ are the dipole moments of the CS and LE states.

\begin{tabular}{|c|c|c|c|c|c|c|c|c|c|}
\hline & \multicolumn{3}{|c|}{$1 a-Z n$} & \multicolumn{3}{|c|}{$1 \beta-\mathrm{ZnA}$} & \multicolumn{3}{|c|}{$1 \beta-Z n B$} \\
\hline & $\mathrm{H}_{\mathrm{DA}}$ & $\Delta \mathrm{E}(\mathrm{eV})$ & TRDM & $\mathrm{H}_{\mathrm{DA}}\left(\mathrm{cm}^{-1}\right)$ & $\Delta \mathrm{E}(\mathrm{eV})$ & TRDM & $\mathrm{H}_{\mathrm{DA}}\left(\mathrm{cm}^{-1}\right)$ & $\Delta \mathrm{E}(\mathrm{eV})$ & TRDM \\
\hline $\mathrm{CS} 1 \rightarrow \mathrm{S}_{0}$ & $-{ }^{\mathrm{a}}$ & $-{ }^{\mathrm{a}}$ & $-{ }^{\mathrm{a}}$ & 1743 (2109) & 1.284 & 1.6 & $1223(1220)$ & 0.879 & 2.10 \\
\hline $\mathrm{CS} 2 \rightarrow \mathrm{S}_{0}$ & $-\mathrm{a}$ & $-{ }^{\mathrm{a}}$ & $-{ }^{a}$ & $2728(3046)$ & 1.398 & 2.4 & 72 (113) & 0.943 & 0.01 \\
\hline
\end{tabular}

${ }^{a}$ The potential energy minima for these states cannot be determined due strong mixing of this excitation with energetically close-lying electronic excited states.

Table S4: GMH-derived electronic couplings $\left(\mathrm{H}_{\mathrm{DA}} \mathrm{S}, \mathrm{cm}^{-1}\right)$ and transition dipole moments (TRDMs, Debye) for thermal charge recombination processes determined at the 1a-Zn, 1及-ZnA,

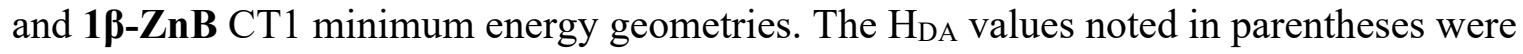
obtained using the same GMH approach but without projecting the transition dipole moments along the charge transfer direction $\left(\mu_{C S}-\mu_{L E}\right)$, where $\mu_{C S}$ and $\mu_{L E}$ are the dipole moments of the CS and LE states.

\begin{tabular}{|c|c|c|c|c|c|c|c|c|c|}
\hline & & $\mathbf{a}-\mathbf{Z n}$ & & & $\beta-Z n A$ & & & $1 \beta-\mathrm{ZnB}$ & \\
\hline & $\begin{array}{c}\mathrm{H}_{\mathrm{DA}} \\
\left(\mathrm{cm}^{-1}\right)\end{array}$ & $\Delta \mathrm{E}(\mathrm{eV})$ & TRDM & $\begin{array}{c}\mathrm{H}_{\mathrm{DA}} \\
\left(\mathrm{cm}^{-1}\right)\end{array}$ & $\begin{array}{c}\Delta \mathrm{E} \\
(\mathrm{eV})\end{array}$ & TRDM & $\begin{array}{c}\mathrm{H}_{\mathrm{DA}} \\
\left(\mathrm{cm}^{-1}\right)\end{array}$ & $\Delta \mathrm{E}(\mathrm{eV})$ & TRDM \\
\hline $\mathrm{CS} 1 \rightarrow \mathrm{S}_{0}$ & $\begin{array}{c}344 \\
(959)\end{array}$ & 0.988 & 0.4 & $\begin{array}{c}366 \\
(1106)\end{array}$ & 0.914 & 0.8 & $\begin{array}{c}688 \\
(692)\end{array}$ & 0.692 & 1.0 \\
\hline $\mathrm{CS} 2 \rightarrow \mathrm{S}_{0}$ & $\begin{array}{c}3555 \\
(3679)\end{array}$ & 1.597 & 2.7 & $\begin{array}{c}3736 \\
(3937)\end{array}$ & 1.542 & 3.2 & $\begin{array}{c}568 \\
(587)\end{array}$ & 1.143 & 0.3 \\
\hline
\end{tabular}


Small solvent and basis set effects were found from the benchmark studies performed at the Franck-Condon geometries of $1 \beta-\mathrm{ZnA}$ and $1 \beta-\mathrm{ZnB}$. The computed results are presented in Tables S5 and S6. While the pbe0 functional underestimates the energies of the charge separated states, it correctly characterized the nature of LE and CT states. When deriving the DA electronic couplings between LE and CS states using the GMH approach, we used the pbe0 (cam-b3lyp) functional computed the transition dipole moments along with the energetics from the mpwb $1 \mathrm{k}$ functional. The comparisons between the transition dipole moments computed using pbe0, camb3lyp and mpwb1k functionals are presented in Tables S7 and S8. Results agree closely, validating the use of the pbe 0 and cam-b3lyp computed transition dipole moments to estimate the electronic coupling between LE and CT states. We further investigated the impacts of the basis set on computed the DA coupling. The couplings derived from the double zeta and triple zeta basis sets, shown in Tables S8 and S9, are in accordance with each other.

Table S5: Vertical excitation energy (eV) and oscillator strength (in the parentheses) of $\mathbf{1 \beta}-\mathbf{Z n A}$ computed using selected methods in the gas phase and in the solution phase based on the ground state optimized geometry obtained at the mpwb1k/def2-SVP level with the CPCM solvent model. B1: def2-SVP; B2: ma-def2-TZVP.

\begin{tabular}{|c|c|c|c|c|c|}
\hline & $\begin{array}{c}\mathrm{RI}-\mathrm{CC} 2 / \mathrm{B} 1 \\
(\mathrm{gas})\end{array}$ & $\begin{array}{c}\mathrm{mpwb} 1 \mathrm{k} / \mathrm{B} 1 \\
(\mathrm{gas})\end{array}$ & $\begin{array}{c}\mathrm{mpwb} 1 \mathrm{k} / \mathrm{B} 1 \\
(\mathrm{cpcm})\end{array}$ & $\begin{array}{c}\mathrm{mpwb} 1 \mathrm{k} / \mathrm{B} 2 \\
(\mathrm{cpcm})\end{array}$ & $\begin{array}{c}\text { cam-b3lyp/B1 } \\
(\mathrm{cpcm})\end{array}$ \\
\hline $\mathrm{S}_{0} \rightarrow \mathrm{CS} 1$ & $2.19(0.046)$ & $1.94(0.019)$ & $1.91(0.035)$ & $1.88(0.032)$ & $1.97(0.033)$ \\
\hline $\mathrm{S}_{0} \rightarrow \mathrm{CS} 2$ & $2.35(0.013)$ & $2.14(0.015)$ & $2.13(0.024)$ & $2.06(0.033)$ & $2.10(0.023)$ \\
\hline $\mathrm{S}_{0} \rightarrow \mathrm{LE} 1$ & $2.57(0.018)$ & $2.41(0.013)$ & $2.39(0.060)$ & $2.35(0.091)$ & $2.40(0.020)$ \\
\hline $\mathrm{S}_{0 \rightarrow \mathrm{LE} 2}$ & $2.69(0.220)$ & $2.43(0.092)$ & $2.41(0.149)$ & $2.36(0.088)$ & $2.45(0.192)$ \\
\hline
\end{tabular}

Table S6: Vertical excitation energy (eV) and oscillator strength (in the parentheses) of $\mathbf{1 \beta}-\mathbf{Z n B}$ computed using selected methods in the gas phase and in the solution phase based on the ground state optimized geometry obtained at the mpwb1k/def2-SVP level with the CPCM solvent model. B1: def2-SVP; B2: ma-def2-TZVP.

\begin{tabular}{|c|c|c|c|c|c|}
\hline & $\begin{array}{c}\text { RI-CC2/B1 } \\
(\mathrm{gas})\end{array}$ & $\begin{array}{c}\text { mpwb1k/B1 } \\
(\mathrm{gas})\end{array}$ & $\begin{array}{c}\text { mpwb1k/B1 } \\
(\mathrm{cpcm})\end{array}$ & $\begin{array}{c}\text { mpwb1k/B2 } \\
(\mathrm{cpcm})\end{array}$ & $\begin{array}{c}\mathrm{pbe} \text { 0/B1 } \\
(\mathrm{cpcm})\end{array}$ \\
\hline $\mathrm{S}_{0} \rightarrow \mathrm{CS} 1$ & $2.39(0.051)$ & $2.23(0.010)$ & $2.17(0.012)$ & $2.11(0.010)$ & $1.63(0.002)$ \\
\hline $\mathrm{S}_{0} \rightarrow \mathrm{CS} 2$ & $2.44(0.013)$ & $2.31(0.003)$ & $2.29(0.005)$ & $2.22(0.001)$ & $1.84(0.001)$ \\
\hline $\mathrm{S}_{0} \rightarrow \mathrm{LE} 1$ & $2.58(0.001)$ & $2.35(0.013)$ & $2.33(0.032)$ & $2.29(0.024)$ & $2.25(0.050)$ \\
\hline $\mathrm{S}_{0} \rightarrow \mathrm{LE} 2$ & $2.72(0.035)$ & $2.41(0.007)$ & $2.38(0.016)$ & $2.31(0.012)$ & $2.27(0.024)$ \\
\hline
\end{tabular}


Table S7: Transition dipole moments (Debye) between the ground state and the two local excited states of $\mathbf{1 \beta}-\mathbf{Z n A}$ computed using mpwb1k and cam-b3lyp functionals (def2SVP/CPCM) based on the ground state optimized geometry obtained at the mpwb1k/def2SVP/CPCM level of theory.

\begin{tabular}{|c|c|c|c|c|c|c|}
\hline & & mpwb1k & & & cam-b3lyp & \\
\hline & $\mu_{x}$ & $\mu_{y}$ & $\mu_{z}$ & $\mu_{x}$ & $\mu_{y}$ & $\mu_{z}$ \\
\hline $\mathrm{S}_{0} \rightarrow \mathrm{LE} 1$ & 0.8491 & -0.5288 & -0.1693 & 0.4625 & -0.2448 & -0.1953 \\
\hline $\mathrm{S}_{0} \rightarrow \mathrm{LE} 2$ & 1.5856 & -0.1129 & -0.0418 & 1.9181 & -0.1712 & -0.2097 \\
\hline
\end{tabular}

Table S8: Transition dipole moments (Debye) between the ground state and the two local excited states of 1/ -ZnB computed using mpwb1k and pbe0 functionals (def2-SVP/CPCM) based on the ground state optimized geometry obtained at the mpwb1k/def2-SVP/CPCM level of theory.

\begin{tabular}{|c|c|c|c|c|c|c|}
\hline & & mpwb1k & & & pbe0 & \\
\hline & $\mu_{x}$ & $\mu_{y}$ & $\mu_{z}$ & $\mu_{x}$ & $\mu_{y}$ & $\mu_{z}$ \\
\hline $\mathrm{S}_{0} \rightarrow \mathrm{LE} 1$ & 0.3679 & -0.6546 & -0.0095 & 0.6869 & -0.8035 & 0.0880 \\
\hline $\mathrm{S}_{0} \rightarrow \mathrm{LE} 2$ & -0.4987 & -0.1722 & -0.0658 & -0.5003 & -0.5675 & -0.1528 \\
\hline
\end{tabular}

Table S9: GMH-derived electronic couplings $\left(\mathrm{H}_{\mathrm{DAS}}, \mathrm{cm}^{-1}\right)$ of $\mathbf{1 \beta - Z n A}$ computed using mpwb1k/CPCM with two basis sets at the minima on the CT states. The $\mathrm{H}_{\mathrm{DA}}$ values noted in parentheses were obtained using the same GMH approach but without projecting the transition dipole moments along the charge transfer direction.

\begin{tabular}{|c|c|c|c|c|}
\hline & CT1 state minimum & & CT2 state minimum & \\
\hline & def2-SVP & ma-def2-TZVP & def2-SVP & ma-def2-TZVP \\
\hline $\mathrm{CS} 1 \rightarrow \mathrm{S}_{0}$ & $366(1106)$ & $301(1095)$ & $1743(2109)$ & $1772(2156)$ \\
\hline $\mathrm{CS} 2 \rightarrow \mathrm{S}_{0}$ & $3736(3937)$ & $3693(3872)$ & $2728(3046)$ & $2740(3019)$ \\
\hline
\end{tabular}

Table S10: GMH-derived electronic couplings $\left(\mathrm{H}_{\mathrm{DA}} \mathrm{S}, \mathrm{cm}^{-1}\right)$ of $\mathbf{1 \beta}-\mathbf{Z n B}$ computed using mpwb1k/CPCM with two basis sets at the minima on the CT states. The $\mathrm{H}_{\mathrm{DA}}$ values noted in parentheses were obtained using the same GMH approach but without projecting the transition dipole moments along the charge transfer direction.

\begin{tabular}{|c|c|c|c|c|}
\hline & CT1 state minimum & & CT2 state minimum & \\
\hline & def2-SVP & ma-def2-TZVP & def2-SVP & ma-def2-TZVP \\
\hline $\mathrm{CS} 1 \rightarrow \mathrm{S}_{0}$ & $688(692)$ & $666(670)$ & $1223(1220)$ & $1203(1206)$ \\
\hline $\mathrm{CS} 2 \rightarrow \mathrm{S}_{0}$ & $568(587)$ & $565(582)$ & $72(113)$ & $53(93)$ \\
\hline
\end{tabular}


Cartesian coordinates of the optimized minima on the ground and excited states potential energy surfaces.

$\mathbf{1 \beta - Z n A}$ ground state equilibrium geometry (Franck-Condon geometry) optimized at mpwb1k/def2-SVP level/CPCM level

$\begin{array}{lrrr}\mathrm{C} & 1.430666 & -2.989109 & -0.575484 \\ \mathrm{C} & 2.382719 & -4.064685 & -0.572146 \\ \mathrm{C} & 3.598283 & -3.507950 & -0.379025 \\ \mathrm{C} & 3.393476 & -2.090030 & -0.266375 \\ \mathrm{~N} & 2.075898 & -1.809022 & -0.409179 \\ \mathrm{C} & 0.052918 & -3.156193 & -0.721151 \\ \mathrm{C} & 4.238843 & 0.226877 & -0.024441 \\ \mathrm{C} & 5.272884 & 1.170204 & 0.298264 \\ \mathrm{C} & 4.719556 & 2.400246 & 0.210801 \\ \mathrm{C} & 3.347008 & 2.210904 & -0.167170 \\ \mathrm{~N} & 3.085817 & 0.886176 & -0.283442 \\ \mathrm{C} & 1.070685 & 3.068110 & -0.655366 \\ \mathrm{C} & 0.181502 & 4.128872 & -1.026635 \\ \mathrm{C} & -1.035350 & 3.569831 & -1.212362 \\ \mathrm{C} & -0.896634 & 2.167399 & -0.939541 \\ \mathrm{~N} & 0.395625 & 1.893356 & -0.635859 \\ \mathrm{C} & -1.817226 & -0.134740 & -0.795349 \\ \mathrm{C} & -2.886535 & -1.104314 & -0.646906 \\ \mathrm{C} & -2.292578 & -2.323563 & -0.680781 \\ \mathrm{C} & -0.883043 & -2.113430 & -0.759481 \\ \mathrm{~N} & -0.624623 & -0.787710 & -0.807423 \\ \mathrm{C} & 2.432925 & 3.247684 & -0.376825 \\ \mathrm{C} & -1.962125 & 1.253202 & -0.957106 \\ \mathrm{C} & 4.417134 & -1.162082 & -0.048260 \\ \mathrm{C} & -4.070253 & 1.389126 & -2.282823 \\ \mathrm{C} & -5.323125 & 1.927050 & -2.523659 \\ \mathrm{C} & -5.829655 & 2.910865 & -1.690086 \\ \mathrm{C} & -5.078899 & 3.350687 & -0.610924 \\ \mathrm{C} & -3.828872 & 2.809426 & -0.367538 \\ \mathrm{C} & -3.308159 & 1.820863 & -1.201578 \\ \mathrm{C} & 6.824305 & -1.376520 & -0.692651 \\ \mathrm{C} & 8.101322 & -1.866079 & -0.475154 \\ \mathrm{C} & 8.361328 & -2.670695 & 0.622835 \\ \mathrm{C} & 7.336131 & -2.983800 & 1.500850 \\ \mathrm{C} & 6.058986 & -2.496126 & 1.281055 \\ \mathrm{C} & 5.785060 & -1.685376 & 0.181808 \\ \mathrm{H} & 2.148433 & -5.109537 & -0.715797 \\ & 4.554723 & -4.008454 & -0.334600 \\ & 6.286114 & 0.920250 & 0.577871\end{array}$




\begin{tabular}{|c|c|c|c|}
\hline $\mathrm{H}$ & 1437 & 269 & \\
\hline 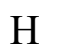 & & 5.164769 & \\
\hline & .942056 & 063858 & -1.526778 \\
\hline & .780049 & -3.279871 & \\
\hline & -5.904182 & 1.579332 & -3.371972 \\
\hline & 234 & 3.333581 & -1.880664 \\
\hline & -5.4 & & 2657 \\
\hline & 30 & -1.6 & 0785 \\
\hline & 14 & -3.0 & \\
\hline & 7.5 & -3.6 & 6089 \\
\hline & 940 & & \\
\hline & -3.2 & 868 & \\
\hline & -3.6 & & \\
\hline & 5.2 & -2.7 & 2721 \\
\hline & 51 & -0.7 & \\
\hline & -0.4 & -4 & 244 \\
\hline & -0.3 & -5. & 17 \\
\hline & -1.1 & -4 & \\
\hline & -0.8 & -6 . & \\
\hline & 27 & -5. & 019 \\
\hline & 83 & -6 & -2 \\
\hline & 692 & -4. & -2 \\
\hline 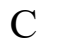 & -1.4 & -7. & -0 \\
\hline $\mathrm{H}$ & -0.7 & -7.7 & 208 \\
\hline $\mathrm{H}$ & -2.1 & -6. & -2 \\
\hline $\mathrm{H}$ & -1.8 & -8 . & -0 \\
\hline $\mathrm{C}$ & 78 & & 00 \\
\hline & 3.9 & & -1 . \\
\hline $\mathrm{C}$ & 2.4 & 5.5 & 11 \\
\hline 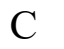 & 4.3 & & \\
\hline$U$ & 70 & & -1 \\
\hline 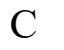 & $2.8^{\prime}$ & & \\
\hline $\mathrm{H}$ & & & \\
\hline $\mathrm{C}$ & $3.8^{\prime}$ & & -0 . \\
\hline $\mathrm{H}$ & 5.1 & & \\
\hline $\mathrm{H}$ & 2.4 & & 684 \\
\hline $\mathrm{H}$ & 4.236457 & & 17495 \\
\hline $\mathrm{C}$ & -4.3 & -0.9 & 4967 \\
\hline $\mathrm{C}$ & -4.75 & -0.1 & 2051 \\
\hline $\mathrm{C}$ & -5.2 & -1.5 & 7626 \\
\hline $\mathrm{C}$ & -3.95 & 645 & 5715 \\
\hline $\mathrm{C}$ & & 0.1 & 0.760668 \\
\hline $\mathrm{C}$ & -6.58 & 1324 & -1.110951 \\
\hline $\mathrm{H}$ & & -2.119065 & -2.032609 \\
\hline $\mathrm{C}$ & -4.546465 & 1.285159 & 2.679545 \\
\hline O & -6.716115 & 1.040094 & 1.717574 \\
\hline
\end{tabular}




$\begin{array}{lrrr}\mathrm{C} & -7.066681 & -0.465281 & -0.165440 \\ \mathrm{H} & -7.261007 & -1.808412 & -1.809595 \\ \mathrm{C} & -5.902887 & 1.628393 & 2.639237 \\ \mathrm{H} & -3.921162 & 1.696383 & 3.463619 \\ \mathrm{H} & -7.781079 & 1.250815 & 1.701350 \\ \mathrm{H} & -8.126874 & -0.240651 & -0.100928 \\ \mathrm{H} & -6.303074 & 2.325455 & 3.367830 \\ \mathrm{C} & -2.614970 & -0.043572 & 2.080389 \\ \mathrm{C} & -1.557964 & 0.989504 & 2.290907 \\ \mathrm{C} & -2.300243 & -1.335209 & 2.261654 \\ \mathrm{C} & -0.192146 & 0.525707 & 2.603284 \\ \mathrm{C} & -0.945577 & -1.792917 & 2.592050 \\ \mathrm{H} & -3.047645 & -2.115438 & 2.157890 \\ \mathrm{C} & 0.100993 & -0.764986 & 2.742156 \\ \mathrm{H} & 0.548753 & 1.311128 & 2.715693 \\ \mathrm{H} & 1.100266 & -1.119680 & 2.975014 \\ \mathrm{O} & -0.695789 & -2.964390 & 2.749999 \\ \mathrm{O} & -1.790830 & 2.170788 & 2.229876\end{array}$

$\mathbf{1} \beta-Z n A$ ground state equilibrium geometry (Franck-Condon geometry) optimized at mpwblk/ma-def2-TZVP level/CPCM

$\begin{array}{lrrl}\mathrm{C} & 1.413160 & -2.975393 & -0.576086 \\ \mathrm{C} & 2.358899 & -4.048582 & -0.591809 \\ \mathrm{C} & 3.570029 & -3.504494 & -0.383058 \\ \mathrm{C} & 3.375640 & -2.093719 & -0.243969 \\ \mathrm{~N} & 2.061837 & -1.803376 & -0.382821 \\ \mathrm{C} & 0.042619 & -3.129759 & -0.732938 \\ \mathrm{C} & 4.235735 & 0.203359 & 0.007121 \\ \mathrm{C} & 5.273128 & 1.137567 & 0.318685 \\ \mathrm{C} & 4.734023 & 2.366079 & 0.223215 \\ \mathrm{C} & 3.363491 & 2.190620 & -0.145334 \\ \mathrm{~N} & 3.088560 & 0.869890 & -0.248479 \\ \mathrm{C} & 1.104226 & 3.062897 & -0.622718 \\ \mathrm{C} & 0.223737 & 4.123979 & -0.990910 \\ \mathrm{C} & -0.993123 & 3.578206 & -1.165785 \\ \mathrm{C} & -0.868809 & 2.180326 & -0.891732 \\ \mathrm{~N} & 0.420039 & 1.896130 & -0.592942 \\ \mathrm{C} & -1.803596 & -0.105512 & -0.775096 \\ \mathrm{C} & -2.873093 & -1.068753 & -0.651124 \\ \mathrm{C} & -2.288837 & -2.284386 & -0.697257 \\ \mathrm{C} & -0.883088 & -2.086543 & -0.761303 \\ \mathrm{~N} & -0.615780 & -0.764427 & -0.788187 \\ \mathrm{C} & 2.463317 & 3.228063 & -0.359763 \\ \mathrm{C} & -1.934701 & 1.277932 & -0.918459\end{array}$




\begin{tabular}{|c|c|c|c|}
\hline $\mathrm{C}$ & 9862 & 9290 & \\
\hline $\mathrm{C}$ & .016459 & 1.439028 & 2360345 \\
\hline & 073 & 662 & \\
\hline & .748706 & 2.986783 & \\
\hline & .011992 & 2778 & \\
\hline 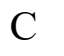 & 964 & 471 & -0 . \\
\hline & -3.26 & & \\
\hline & 93 & & \\
\hline & & & \\
\hline 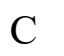 & 8.31 & -2. & \\
\hline 4 & 7.2 & -3. & \\
\hline $\mathrm{C}$ & 6.02 & -2.5 & \\
\hline & 5.7 & & \\
\hline $\mathrm{H}$ & 2.12 & -5. & 428 \\
\hline & 4.5 & -4 & -0 . \\
\hline $\mathrm{H}$ & 6.2 & & \\
\hline H & 5.21 & 3.3 & 0. \\
\hline 1 & 0.5 & & \\
\hline $\mathrm{H}$ & -1.8 & & 88 \\
\hline H & -2.7 & -3.2 & \\
\hline $\mathrm{H}$ & -5.8 & & 82 \\
\hline I & -6.7 & & \\
\hline H & -5.4 & & \\
\hline H & 8.8 & -1. & \\
\hline $\mathrm{H}$ & 9.3 & & \\
\hline $\mathrm{H}$ & 7.4 & -3 & \\
\hline $\mathrm{Zn}$ & 1.2 & & \\
\hline 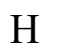 & -3.2 & & \\
\hline H & -3.6 & 0.6 & -2 \\
\hline $\mathrm{H}$ & 5.2 & -2.8 & \\
\hline $\mathrm{H}$ & 6.6 & -0.7 & \\
\hline $\mathrm{C}$ & -0.4 & -4.5 & \\
\hline $\mathrm{C}$ & -0.3 & -5 & \\
\hline 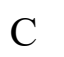 & -1.1 & -4 & \\
\hline 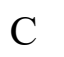 & -0.8 & -6.6 & \\
\hline $\mathrm{H}$ & 0.1 & -5.1 & 552 \\
\hline 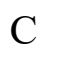 & -1.67 & -6.177560 & -2 \\
\hline $\mathrm{H}$ & -1.3 & -4 & -2 \\
\hline $\mathrm{C}$ & $-1.4 \mathrm{C}$ & -7.082815 & -1. \\
\hline $\mathrm{H}$ & -0.68 & -7.39 & 948 \\
\hline $\mathrm{H}$ & -2.19 & -6.469586 & -2. \\
\hline $\mathrm{H}$ & -1.88 & -8.08 & -1.160841 \\
\hline $\mathrm{C}$ & 2.98 & 4.609565 & -0.314603 \\
\hline 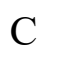 & 3.9 & 5.018254 & -1 . \\
\hline $\mathrm{C}$ & 2.480915 & 5.525361 & 0.594749 \\
\hline 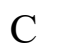 & 4.468317 & 6.308043 & -1.14199 \\
\hline
\end{tabular}




$\begin{array}{lrrc}\mathrm{H} & 4.377747 & 4.316001 & -1.897601 \\ \mathrm{C} & 2.966701 & 6.813922 & 0.639383 \\ \mathrm{H} & 1.704654 & 5.216481 & 1.274576 \\ \mathrm{C} & 3.961532 & 7.209757 & -0.229982 \\ \mathrm{H} & 5.240104 & 6.610415 & -1.829046 \\ \mathrm{H} & 2.568469 & 7.509946 & 1.357755 \\ \mathrm{H} & 4.339586 & 8.217145 & -0.197332 \\ \mathrm{C} & -4.299931 & -0.883175 & -0.388805 \\ \mathrm{C} & -4.804520 & -0.122941 & 0.701878 \\ \mathrm{C} & -5.172225 & -1.476503 & -1.258099 \\ \mathrm{C} & -4.023411 & 0.398490 & 1.772509 \\ \mathrm{C} & -6.192318 & 0.156153 & 0.709073 \\ \mathrm{C} & -6.550267 & -1.283966 & -1.174058 \\ \mathrm{H} & -4.766463 & -2.060373 & -2.066916 \\ \mathrm{C} & -4.591178 & 1.268816 & 2.661945 \\ \mathrm{C} & -6.731584 & 1.033771 & 1.662666 \\ \mathrm{C} & -7.043730 & -0.442304 & -0.234295 \\ \mathrm{H} & -7.202928 & -1.761257 & -1.884366 \\ \mathrm{C} & -5.941244 & 1.610173 & 2.600454 \\ \mathrm{H} & -3.987360 & 1.664605 & 3.458763 \\ \mathrm{H} & -7.788438 & 1.240040 & 1.628493 \\ \mathrm{H} & -8.096735 & -0.220197 & -0.186246 \\ \mathrm{H} & -6.352452 & 2.292133 & 3.324223 \\ \mathrm{C} & -2.665136 & -0.061726 & 2.101253 \\ \mathrm{C} & -1.604284 & 0.944463 & 2.373933 \\ \mathrm{C} & -2.375664 & -1.352449 & 2.263356 \\ \mathrm{C} & -0.265805 & 0.459849 & 2.740790 \\ \mathrm{C} & -1.050225 & -1.830050 & 2.648236 \\ \mathrm{H} & -3.121950 & -2.113926 & 2.112463 \\ \mathrm{C} & 0.002465 & -0.828681 & 2.860833 \\ \mathrm{H} & 0.472534 & 1.226693 & 2.903021 \\ \mathrm{H} & 0.976608 & -1.201156 & 3.128599 \\ \mathrm{O} & -0.826652 & -3.006231 & 2.805263 \\ \mathrm{O} & -1.812781 & 2.128333 & 2.312645\end{array}$

1及-ZnA CT1 state equilibrium geometry optimized at TD-mpwb1k/def2-SVP level/CPCM level

$\begin{array}{llll}\mathrm{C} & 1.377805 & -2.987493 & -0.798599 \\ \mathrm{C} & 2.364779 & -4.023015 & -0.858985 \\ \mathrm{C} & 3.549946 & -3.442933 & -0.552516 \\ \mathrm{C} & 3.275168 & -2.057306 & -0.315723 \\ \mathrm{~N} & 1.971933 & -1.804492 & -0.502223 \\ \mathrm{C} & 0.007108 & -3.179955 & -0.963332 \\ \mathrm{C} & 4.045061 & 0.276668 & 0.112893 \\ \mathrm{C} & 5.006930 & 1.242447 & 0.552100\end{array}$




$\begin{array}{lrrr}\mathrm{C} & 4.444998 & 2.461710 & 0.364713 \\ \mathrm{C} & 3.141100 & 2.228933 & -0.179098 \\ \mathrm{~N} & 2.912123 & 0.916349 & -0.295039 \\ \mathrm{C} & 0.916906 & 3.054198 & -0.942794 \\ \mathrm{C} & 0.024837 & 4.075436 & -1.423207 \\ \mathrm{C} & -1.178765 & 3.488030 & -1.590763 \\ \mathrm{C} & -1.017571 & 2.111295 & -1.209497 \\ \mathrm{~N} & 0.249124 & 1.864528 & -0.884165 \\ \mathrm{C} & -1.921623 & -0.192514 & -0.927152 \\ \mathrm{C} & -2.947438 & -1.169416 & -0.617612 \\ \mathrm{C} & -2.350169 & -2.382828 & -0.728334 \\ \mathrm{C} & -0.964946 & -2.144569 & -0.964693 \\ \mathrm{~N} & -0.722197 & -0.833286 & -1.059676 \\ \mathrm{C} & 2.229980 & 3.260134 & -0.558495 \\ \mathrm{C} & -2.094546 & 1.177548 & -1.108475 \\ \mathrm{C} & 4.251728 & -1.100244 & 0.067190 \\ \mathrm{C} & -4.389216 & 1.252943 & -2.082568 \\ \mathrm{C} & -5.666557 & 1.784006 & -2.120886 \\ \mathrm{C} & -6.019012 & 2.808740 & -1.257316 \\ \mathrm{C} & -5.089208 & 3.307387 & -0.357029 \\ \mathrm{C} & -3.810254 & 2.784896 & -0.319986 \\ \mathrm{C} & -3.450026 & 1.745685 & -1.180651 \\ \mathrm{C} & 6.724069 & -1.181908 & -0.262293 \\ \mathrm{C} & 7.974867 & -1.671551 & 0.071400 \\ \mathrm{H} & 8.110667 & -2.589583 & 1.100311 \\ \mathrm{H} & -4.857458 & -2.886096 & 1.988456 \\ \mathrm{C} & 6.988682 & -3.023642 & 1.789141 \\ \mathrm{C} & 5.735635 & -2.546826 & 1.447843 \\ \mathrm{C} & 5.589350 & -1.613826 & 0.422073 \\ \mathrm{H} & 2.178992 & -5.054774 & -1.119191 \\ \mathrm{H} & 4.523697 & -3.908860 & -0.513359 \\ \mathrm{H} & 5.979220 & 1.020720 & 0.967311 \\ \mathrm{H} & 4.870914 & 3.427166 & 0.595019 \\ \mathrm{H} & 0.294690 & 5.102168 & -1.623091 \\ \mathrm{H} & -2.091745 & 3.938258 & -1.950544 \\ \mathrm{H} & -2.796588 & -3.342445 & -0.510854 \\ \mathrm{H} & -6.390648 & 1.394852 & -2.829309 \\ \mathrm{H} & -7.023732 & 3.218910 & -1.285044 \\ \mathrm{H} & -5.366262 & 4.100249 & 0.330155 \\ \mathrm{H} & -0982391 & -1.335342 & -0.478182 \\ \mathrm{H} & -2.969404 & 1.364848 \\ \mathrm{H} & -0.468521 & -1.073192\end{array}$




\begin{tabular}{|c|c|c|c|}
\hline & 0.491153 & -4.562473 & \\
\hline & & -5.456551 & \\
\hline & .277427 & 4513 & \\
\hline & 0.683475 & -6.753548 & -0.0 \\
\hline & 0.359783 & -5.098082 & \\
\hline & -1.741158 & -6.286754 & -2.1 \\
\hline & -1.509955 & -4.287993 & \\
\hline & -1.4 & -7.1 & -1.1 \\
\hline & -0.4 & -7. & \\
\hline & -2.3 & 1780 & -3. \\
\hline & -1.8 & -8 & \\
\hline & 2.72 & 4.6 & -0.5 \\
\hline & 3.8 & & -1.2 \\
\hline C & 2.08 & 04 & \\
\hline & 4.2 & & -1.2 \\
\hline $\mathrm{H}$ & 4.3 & & \\
\hline & 2.5 & 6.9 & \\
\hline $\mathrm{H}$ & 1.2 & & \\
\hline & 3.6 & 7.2 & -0. \\
\hline & 5.1 & & -1. \\
\hline & 2.0 & 7.6 & \\
\hline H & 4.0 & & -0. \\
\hline C & -4.2 & -0. & -0 . \\
\hline$y$ & & & \\
\hline C & -5.3 & -1. & -0 . \\
\hline & -3.5 & & \\
\hline & -5.8 & & \\
\hline & -6.6 & -1.3 & -0 . \\
\hline $\mathrm{H}$ & -5.1 & -2 & -1 \\
\hline & -3.8 & 1.2 & \\
\hline C & -6.1 & 1.0 & 2.4 \\
\hline & -6.9 & -0.4 & \\
\hline H & & & \\
\hline & -5.20 & 1.6 & \\
\hline & -3.0 & & \\
\hline 2. & -7.2 & 1.2 & 32 \\
\hline & -7.9 & -0.2 & \\
\hline-1 & -5.43 & 74 & 72 \\
\hline & -2.06 & -0.00 & \\
\hline 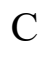 & -1.0 & 27 & 20 \\
\hline & -1.6 & -1.3 & \\
\hline 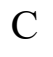 & 0.3 & & \\
\hline & -0.292659 & 1465 & 2.139607 \\
\hline & -2.418817 & -2.092466 & 2.177643 \\
\hline 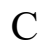 & 0.684135 & -0.670152 & 2.102143 \\
\hline & 1.045774 & 1.443033 & 1.98766 \\
\hline
\end{tabular}




$\begin{array}{rrrr}\mathrm{H} & 1.727342 & -0.953998 & 2.208997 \\ \mathrm{O} & 0.023328 & -2.926518 & 2.195081 \\ \mathrm{O} & -1.371105 & 2.246743 & 1.727008\end{array}$

1ß-ZnA CT2 state equilibrium geometry optimized at TD-mpwb1k/def2-SVP level/CPCM level

$\begin{array}{lrrr}\mathrm{C} & 1.502126 & -2.987431 & -0.721495 \\ \mathrm{C} & 2.528824 & -4.005137 & -0.692834 \\ \mathrm{C} & 3.689656 & -3.374514 & -0.441104 \\ \mathrm{C} & 3.381376 & -1.963618 & -0.322751 \\ \mathrm{~N} & 2.066116 & -1.769536 & -0.535264 \\ \mathrm{C} & 0.140816 & -3.253846 & -0.854013 \\ \mathrm{C} & 4.053591 & 0.396081 & 0.004683 \\ \mathrm{C} & 5.010010 & 1.417461 & 0.382493 \\ \mathrm{C} & 4.388601 & 2.601434 & 0.244115 \\ \mathrm{C} & 3.046680 & 2.317398 & -0.224380 \\ \mathrm{~N} & 2.881497 & 0.977948 & -0.326789 \\ \mathrm{C} & 0.780291 & 3.001127 & -0.944824 \\ \mathrm{C} & -0.164265 & 4.002940 & -1.407504 \\ \mathrm{C} & -1.320567 & 3.363738 & -1.637335 \\ \mathrm{C} & -1.103139 & 1.971887 & -1.290008 \\ \mathrm{~N} & 0.200851 & 1.792214 & -0.959462 \\ \mathrm{C} & -1.859427 & -0.337505 & -0.881556 \\ \mathrm{C} & -2.858682 & -1.344747 & -0.486021 \\ \mathrm{C} & -2.234385 & -2.540735 & -0.597393 \\ \mathrm{C} & -0.856307 & -2.269882 & -0.865389 \\ \mathrm{~N} & -0.662709 & -0.933750 & -1.007021 \\ \mathrm{C} & 2.094818 & 3.288544 & -0.536313 \\ \mathrm{C} & -2.113585 & 1.018712 & -1.180089 \\ \mathrm{C} & 4.328989 & -0.974576 & -0.018120 \\ \mathrm{C} & -4.374742 & 0.887979 & -2.236248 \\ \mathrm{C} & -5.682484 & 1.328457 & -2.353058 \\ \mathrm{C} & -6.132976 & 2.383087 & -1.575766 \\ \mathrm{C} & -5.273743 & 2.993108 & -0.674421 \\ \mathrm{C} & -3.969767 & 2.549184 & -0.550463 \\ \mathrm{C} & -3.505826 & 1.491790 & -1.333024 \\ \mathrm{C} & 6.780761 & -1.037451 & -0.503497 \\ \mathrm{C} & 8.067889 & -1.451919 & -0.204482 \\ \mathrm{C} & 8.302166 & -2.249822 & 0.903967 \\ \mathrm{C} & 7.242649 & -2.631294 & 1.711556 \\ \mathrm{C} & 5.955651 & -2.217301 & 1.412161 \\ \mathrm{C} & 5.708376 & -1.414634 & 0.300963 \\ \mathrm{H} & 2.363961 & -5.060771 & -0.852696 \\ \mathrm{H} & 4.676447 & -3.806339 & -0.358052 \\ \mathrm{H} & 6.017507 & 1.233277 & 0.726250 \\ \mathrm{H} & 4.782735 & 3.585324 & 0.452663\end{array}$




\begin{tabular}{|c|c|c|c|}
\hline 1 & 058301 & & \\
\hline$H$ & -2.244933 & & \\
\hline & 220 & -3.510181 & -0 \\
\hline & -6.351424 & 97 & \\
\hline & 476 & & \\
\hline & -5.625564 & 84 & -0. \\
\hline & 8.89 & -1.15 & \\
\hline & 9.31 & -2.5 & \\
\hline & 7.4 & -3.2 & \\
\hline $\mathrm{Zn}$ & 566 & & \\
\hline & -3.29 & & \\
\hline & -4.02 & 0.0 & -2 \\
\hline & 84 & -2.5 & \\
\hline & 6.5 & -0.4 & -1 . \\
\hline & 38 & -4.6 & \\
\hline & -0.0 & -5. & \\
\hline & -0.9 & -5.2 & -1 . \\
\hline & -0.5 & -6. & \\
\hline H & 0.3 & -4. & \\
\hline & -1.3 & -6.5 & \\
\hline $\mathrm{H}$ & -1.1 & -4.6 & -2 . \\
\hline & -1.1 & -7.3 & \\
\hline & -0.3 & -7.7 & \\
\hline & -1.8 & -6.9 & -2 \\
\hline H & -1.4 & -8.3 & -0 \\
\hline & 2.4 & 4.7 & -0. \\
\hline & & 5.2 & -1 . \\
\hline & 1.7 & 5.5 & \\
\hline$\gamma$ & 3.8 & 6.5 & -1. \\
\hline 11 & 4.0 & & \\
\hline $\mathrm{C}$ & & & \\
\hline $\mathrm{H}$ & 0.98 & & \\
\hline $\mathrm{C}$ & 3.15 & & \\
\hline $\mathrm{H}$ & 4.6 & & -1 . \\
\hline $\mathrm{H}$ & 1.5 & & \\
\hline $\mathrm{H}$ & 3.4 & 8.4 & $-0 .($ \\
\hline $\mathrm{C}$ & -4.19 & -1.1 & \\
\hline $\mathrm{C}$ & -4.4 & -0.1 & 43 \\
\hline $\mathrm{C}$ & -5.2 & -1.8 & -0 \\
\hline $\mathrm{C}$ & -3.5 & 0.5 & 50 \\
\hline $\mathrm{C}$ & -5.87 & $0.0^{\prime}$ & 99 \\
\hline $\mathrm{C}$ & & -1.6 & -0.1 \\
\hline $\mathrm{H}$ & -4.9 & -2.60 & -1.2 \\
\hline $\mathrm{C}$ & & 1.5 & \\
\hline $\mathrm{C}$ & -6.262627 & 1.096655 & 2.210380 \\
\hline$G$ & -6.876185 & -0.683713 & 0.67457 \\
\hline
\end{tabular}




$\begin{array}{lrrl}\mathrm{H} & -7.321538 & -2.275883 & -0.674649 \\ \mathrm{C} & -5.322971 & 1.827020 & 2.876300 \\ \mathrm{H} & -3.228671 & 2.051766 & 3.299388 \\ \mathrm{H} & -7.322029 & 1.285902 & 2.353787 \\ \mathrm{H} & -7.914801 & -0.456935 & 0.895478 \\ \mathrm{H} & -5.617402 & 2.621247 & 3.554516 \\ \mathrm{C} & -2.096142 & 0.167199 & 1.972062 \\ \mathrm{C} & -1.100362 & 1.238176 & 1.876130 \\ \mathrm{C} & -1.698638 & -1.116109 & 2.184012 \\ \mathrm{C} & 0.279726 & 0.823408 & 1.987384 \\ \mathrm{C} & -0.313393 & -1.537704 & 2.240862 \\ \mathrm{H} & -2.436868 & -1.906571 & 2.283660 \\ \mathrm{C} & 0.660525 & -0.475615 & 2.152144 \\ \mathrm{H} & 1.012284 & 1.625688 & 1.944348 \\ \mathrm{H} & 1.707905 & -0.751928 & 2.241851 \\ \mathrm{O} & -0.001807 & -2.728784 & 2.340394 \\ \mathrm{O} & -1.402100 & 2.424685 & 1.695402\end{array}$

1及-ZnA LE1 state equilibrium geometry

$\begin{array}{lrrr}\mathrm{C} & 1.470990 & -2.986474 & -0.612444 \\ \mathrm{C} & 2.450468 & -4.036755 & -0.675566 \\ \mathrm{C} & 3.654781 & -3.460491 & -0.476941 \\ \mathrm{C} & 3.418852 & -2.052833 & -0.288763 \\ \mathrm{~N} & 2.091998 & -1.795444 & -0.400988 \\ \mathrm{C} & 0.098348 & -3.187075 & -0.755010 \\ \mathrm{C} & 4.221217 & 0.283401 & 0.017237 \\ \mathrm{C} & 5.203193 & 1.232232 & 0.440398 \\ \mathrm{C} & 4.626086 & 2.458674 & 0.343947 \\ \mathrm{C} & 3.297994 & 2.248722 & -0.137473 \\ \mathrm{~N} & 3.074151 & 0.922009 & -0.309592 \\ \mathrm{C} & 1.013740 & 3.059484 & -0.709393 \\ \mathrm{C} & 0.122632 & 4.089019 & -1.158889 \\ \mathrm{C} & -1.081768 & 3.506570 & -1.350595 \\ \mathrm{C} & -0.934793 & 2.119777 & -1.003395 \\ \mathrm{~N} & 0.352569 & 1.873677 & -0.655550 \\ \mathrm{C} & -1.829638 & -0.199245 & -0.816340 \\ \mathrm{C} & -2.876571 & -1.170838 & -0.593107 \\ \mathrm{C} & -2.266363 & -2.391372 & -0.643990 \\ \mathrm{C} & -0.875322 & -2.161810 & -0.791474 \\ \mathrm{~N} & -0.632237 & -0.831586 & -0.883295 \\ \mathrm{C} & 2.362078 & 3.271857 & -0.394524 \\ \mathrm{C} & -1.993215 & 1.195732 & -1.003947 \\ \mathrm{C} & 4.426736 & -1.114273 & -0.037938 \\ \mathrm{C} & -4.137150 & 1.242955 & -2.275893 \\ \mathrm{C} & -5.392524 & 1.773504 & -2.513991\end{array}$




\begin{tabular}{|c|c|c|c|}
\hline $\mathrm{C}$ & 3093 & 37 & \\
\hline $\mathrm{C}$ & .093306 & 3.304318 & \\
\hline & 7048 & & \\
\hline & .339809 & .740663 & \\
\hline & 6.860728 & & \\
\hline & 5143 & 701 & \\
\hline & 732 & & \\
\hline 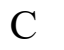 & 683 & -3.0 & \\
\hline 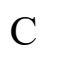 & & & \\
\hline 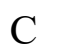 & 5.7 & -1.6 & \\
\hline $\mathrm{H}$ & 787 & -5.0 & 421 \\
\hline 11 & 470 & -3.9 & \\
\hline & 6.1 & & \\
\hline $\mathrm{H}$ & 097 & 3.4 & \\
\hline & 0.3 & 30 & -1 \\
\hline $\mathrm{H}$ & -1.9 & & \\
\hline H & -2.7 & -3.3 & -0 \\
\hline $\mathrm{H}$ & -5.9 & & \\
\hline H & -6.8 & 3.2 & \\
\hline $\mathrm{H}$ & -5. & 4.1 & \\
\hline $\mathrm{H}$ & 8.9 & -1.2 & -1 \\
\hline $\mathrm{H}$ & 9.4 & -2.9 & \\
\hline $\mathrm{H}$ & 7.5 & -3 & \\
\hline $\mathrm{Zn}$ & 1.2 & & \\
\hline $\mathrm{H}$ & -3.2 & & \\
\hline $\mathrm{H}$ & -3.7 & 0.4 & -2 \\
\hline $\mathrm{H}$ & 5.2 & -2.8 & \\
\hline $\mathrm{H}$ & 6.6 & -0.4 & \\
\hline 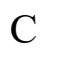 & 847 & -4.5 & -0 \\
\hline 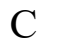 & -0.1 & -5 & 731 \\
\hline $\mathrm{C}$ & -1.1 & -5.0 & -1 \\
\hline $\mathrm{C}$ & -0.6 & -6.7 & \\
\hline $\mathrm{H}$ & & -5.0 & \\
\hline 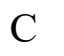 & -1.6 & -6.3 & \\
\hline $\mathrm{H}$ & -1.3 & -4.3 & -2 \\
\hline 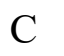 & -1.3 & -7.1 & -0 \\
\hline 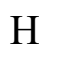 & -0.41 & -7.426921 & \\
\hline 11 & -2.1 & -6.6 & -2.790659 \\
\hline $\mathrm{H}$ & -1.713819 & -8.2 & -0.917959 \\
\hline $\mathrm{C}$ & 2.8 & 4.6 & -0. \\
\hline $\mathrm{C}$ & 3.919298 & 5.100135 & -1.082412 \\
\hline $\mathrm{C}$ & & & \\
\hline $\mathrm{C}$ & 777 & 6.41 & -1.010030 \\
\hline $\mathrm{H}$ & 4.410500 & 4.399217 & -1.750205 \\
\hline $\mathrm{C}$ & 2.650954 & 6.891442 & 0.605115 \\
\hline 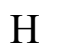 & 1.370299 & 5.253313 & 1.13385 \\
\hline
\end{tabular}




$\begin{array}{lrrr}\mathrm{C} & 3.724876 & 7.310341 & -0.164102 \\ \mathrm{H} & 5.192230 & 6.733891 & -1.621676 \\ \mathrm{H} & 2.156160 & 7.587199 & 1.275157 \\ \mathrm{H} & 4.070551 & 8.337401 & -0.104724 \\ \mathrm{C} & -4.293602 & -0.984097 & -0.270035 \\ \mathrm{C} & -4.766761 & -0.149727 & 0.792545 \\ \mathrm{C} & -5.200508 & -1.643529 & -1.068815 \\ \mathrm{C} & -3.949413 & 0.438569 & 1.809963 \\ \mathrm{C} & -6.162529 & 0.129663 & 0.825633 \\ \mathrm{C} & -6.580499 & -1.445493 & -0.951165 \\ \mathrm{H} & -4.817861 & -2.285144 & -1.856343 \\ \mathrm{C} & -4.496895 & 1.370565 & 2.663061 \\ \mathrm{C} & -6.676395 & 1.071510 & 1.740407 \\ \mathrm{C} & -7.046817 & -0.535624 & -0.050366 \\ \mathrm{H} & -7.261456 & -1.974784 & -1.609472 \\ \mathrm{C} & -5.853576 & 1.709408 & 2.620322 \\ \mathrm{H} & -3.862125 & 1.820424 & 3.417323 \\ \mathrm{H} & -7.742600 & 1.276309 & 1.727524 \\ \mathrm{H} & -8.106772 & -0.310652 & 0.017367 \\ \mathrm{H} & -6.247785 & 2.441715 & 3.317052 \\ \mathrm{C} & -2.571981 & 0.007133 & 2.113844 \\ \mathrm{C} & -1.515401 & 1.035235 & 2.288917 \\ \mathrm{C} & -2.262766 & -1.289402 & 2.298482 \\ \mathrm{C} & -0.162052 & 0.561246 & 2.601261 \\ \mathrm{C} & -0.912390 & -1.760163 & 2.606272 \\ \mathrm{H} & -3.019174 & -2.062026 & 2.200662 \\ \mathrm{C} & 0.128261 & -0.737089 & 2.745418 \\ \mathrm{H} & 0.588822 & 1.338509 & 2.705744 \\ \mathrm{H} & 1.130161 & -1.088051 & 2.972978 \\ \mathrm{O} & -0.668224 & -2.942493 & 2.743636 \\ \mathrm{O} & -1.741074 & 2.223043 & 2.183429\end{array}$

$\mathbf{1} \beta-Z n B$ ground state equilibrium geometry (Franck-Condon geometry) optimized at mpwblk/def2-SVP level/CPCM
C $\quad 1.314102 \quad-2.985920 \quad-0.598962$
C $\quad 2.194685-4.119550 \quad-0.554956$
C $\quad 3.434128 \quad-3.640764 \quad-0.307955$
$\begin{array}{llll}\text { C } & 3.320373 & -2.211867 & -0.232709\end{array}$
N $\quad 2.027342-1.848442 \quad-0.415592$
$\begin{array}{llll}\text { C } & -0.069487 & -3.063292 & -0.777637\end{array}$
$\begin{array}{llll}\text { C } & 4.313915 & 0.043607 & 0.029760\end{array}$
$\begin{array}{llll}\text { C } & 5.433904 & 0.917875 & 0.241514\end{array}$
C $\quad 4.963715 \quad 2.181246 \quad 0.147361$
C $\quad 3.558455 \quad 2.079483 \quad-0.135001$ 


\begin{tabular}{|c|c|c|c|}
\hline$N$ & 71 & 6619 & \\
\hline , & & & \\
\hline & 94935 & 53 & \\
\hline & .759313 & .735405 & 436 \\
\hline & 466 & & 902 \\
\hline & & 43 & 377 \\
\hline & -1.7 & & \\
\hline & -2.889713 & -0.843069 & \\
\hline 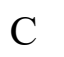 & -2.3 & -2. & \\
\hline 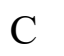 & -0.9 & -1.964617 & \\
\hline & -0.6 & -0.6 & \\
\hline 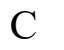 & 2.7 & $3.1^{\prime}$ & \\
\hline & -1.8 & & \\
\hline 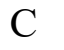 & 4.3 & -1.3 & \\
\hline $\mathrm{C}$ & -3.9 & 67 & \\
\hline ¿ & -5.1 & & \\
\hline C & -5.5 & 3.5 & \\
\hline $\mathrm{C}$ & -4.7 & & \\
\hline C & -3.5 & 3.0 & \\
\hline 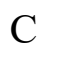 & -3.1 & & \\
\hline $\mathrm{C}$ & 6.4 & -2.5 & \\
\hline C & 7.6 & -3 & \\
\hline $\mathrm{C}$ & 60 & -3. & \\
\hline C & 7.5 & -2.4 & \\
\hline $\mathrm{C}$ & & -1.8 & \\
\hline 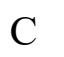 & 5.7 & -1.9 & \\
\hline $\mathrm{H}$ & & -5 & \\
\hline H & 4.3 & -4.2 & \\
\hline $\mathrm{H}$ & 6.4 & 0.6 & \\
\hline $\mathrm{H}$ & 5.5 & 3.1 & \\
\hline $\mathrm{H}$ & 0.8 & 5.2 & \\
\hline $\mathrm{H}$ & -1.6 & 4.294871 & \\
\hline $\mathrm{H}$ & -2.9 & -3.0 & \\
\hline $\mathrm{H}$ & -5.7 & 2.4 & \\
\hline $\mathrm{H}$ & -6.4 & 4.050426 & \\
\hline $\mathrm{H}$ & -5.0 & 4.4 & \\
\hline $\mathrm{H}$ & 8.192929 & -3.6 & \\
\hline $\mathrm{H}$ & 9.2 & -3.5 & \\
\hline $\mathrm{H}$ & 8.002804 & -2.406770 & \\
\hline $\mathrm{Zn}$ & & & \\
\hline $\mathrm{H}$ & -2.9 & 3.234335 & \\
\hline $\mathrm{H}$ & -3.56 & 1.241508 & -2. \\
\hline $\mathrm{H}$ & 5.784594 & -1.406851 & \\
\hline $\mathrm{H}$ & 5.97 & -2.644861 & -1 \\
\hline $\mathrm{C}$ & -0.681129 & -4.407851 & -0.90 \\
\hline$C$ & -0.583205 & -5.345513 & 0.118679 \\
\hline
\end{tabular}




\begin{tabular}{|c|c|c|c|}
\hline & 35015 & 54240 & \\
\hline & 172952 & -6.592666 & 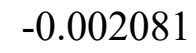 \\
\hline & .039731 & -5.087513 & 745 \\
\hline & 1.972164 & -6.002118 & -2.1 \\
\hline & -1.465174 & -4.033040 & \\
\hline & 9024 & -6.925060 & -1 \\
\hline & -1.0918 & -7.307084 & 957 \\
\hline & -2.511 & -6.2 & -3. \\
\hline & -2.3 & -7.9 & \\
\hline & 3.313875 & 4.527740 & -0.2 \\
\hline & 4.2 & & -1.2 \\
\hline$y$ & 2.9507 & 5.445989 & 0.6 \\
\hline & 4.8 & & -1.2 \\
\hline H & 4.5 & 13 & -2.0 \\
\hline & 3.51 & 6.7 & $0 .^{\prime}$ \\
\hline H & 2.2 & & \\
\hline & 4.45 & 7.0 & -0.2 \\
\hline & 5.5 & & -1 \\
\hline & 3.225 & & 09 \\
\hline & 4.89 & & -0.2 \\
\hline 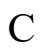 & -4.3 & -0. & -0 \\
\hline & -4.9 & & \\
\hline $\mathrm{C}$ & -5.1 & -1 . & 638 \\
\hline & -4.1 & & 1.7 \\
\hline C & -6.2 & & \\
\hline & -6.5 & -0.7 & 024 \\
\hline $\mathrm{H}$ & -4.7 & -1 & 053 \\
\hline & $-4.7^{\prime}$ & & 47 \\
\hline C & -6.8 & 1.2 & 24 \\
\hline & -7.0 & 0.0 & -0.5 \\
\hline $\mathrm{H}$ & -7.13 & -1. & -2. \\
\hline & -6.0 & & 2.6 \\
\hline H & & & \\
\hline $\mathrm{H}$ & -7.884 & & 34 \\
\hline & -8.112 & 0.2 & -0.5 \\
\hline 2 & $-6.534 c$ & 2.2 & 503 \\
\hline & -2.8637 & -0.170008 & 980 \\
\hline $\mathrm{C}$ & -1.784994 & 0.5 & 003 \\
\hline & -2.790562 & -1.655157 & 6592 \\
\hline $\mathrm{C}$ & -0.4751 & -0.0 & 01 \\
\hline U & -1.805355 & 1.653488 & 2847 \\
\hline 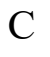 & -1.4634 & -2.252645 & 2.465494 \\
\hline 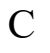 & -0.385311 & -1.501116 & 2.672899 \\
\hline & -1.435933 & -3.337745 & 2.483093 \\
\hline 2 & 0.597411 & -1.922636 & 2.861016 \\
\hline$\Omega$ & -3.781473 & -2.337666 & 2.192909 \\
\hline
\end{tabular}




\section{O $\quad 0.502853 \quad 0.655972 \quad 2.838991$}

$\mathbf{1} \beta-Z n B$ ground state equilibrium geometry (Franck-Condon geometry) optimized at mpwb1k/ma-def2-TZVP level/CPCM

\begin{tabular}{|c|c|c|c|}
\hline $\mathrm{C}$ & 1.317736 & -2.967781 & -0.598869 \\
\hline $\mathrm{C}$ & 2.196439 & -4.095570 & -0.566206 \\
\hline $\mathrm{C}$ & 3.432182 & -3.620963 & -0.330384 \\
\hline $\mathrm{C}$ & 3.323912 & -2.197859 & -0.248463 \\
\hline $\mathrm{N}$ & 2.031827 & -1.832787 & -0.419255 \\
\hline $\mathrm{C}$ & -0.060287 & -3.043192 & -0.762269 \\
\hline $\mathrm{C}$ & 4.313333 & 0.043847 & 0.029798 \\
\hline $\mathrm{C}$ & 5.427980 & 0.915879 & 0.238394 \\
\hline $\mathrm{C}$ & 4.958636 & 2.173428 & 0.160042 \\
\hline $\mathrm{C}$ & 3.557111 & 2.076839 & -0.110907 \\
\hline $\mathrm{N}$ & 3.195737 & 0.776336 & -0.169173 \\
\hline $\mathrm{C}$ & 1.341292 & 3.079255 & -0.528751 \\
\hline $\mathrm{C}$ & 0.508718 & 4.199453 & -0.832673 \\
\hline $\mathrm{C}$ & -0.738314 & 3.725886 & -0.995681 \\
\hline $\mathrm{C}$ & -0.680775 & 2.309864 & -0.786069 \\
\hline $\mathrm{N}$ & 0.596895 & 1.949638 & -0.528728 \\
\hline $\mathrm{C}$ & -1.746397 & 0.076603 & -0.767687 \\
\hline $\mathrm{C}$ & -2.869916 & -0.832552 & -0.680428 \\
\hline $\mathrm{C}$ & -2.342274 & -2.076500 & -0.726038 \\
\hline $\mathrm{C}$ & -0.927831 & -1.951743 & -0.779058 \\
\hline $\mathrm{N}$ & -0.594711 & -0.643394 & -0.772879 \\
\hline $\mathrm{C}$ & 2.711268 & 3.165057 & -0.298058 \\
\hline $\mathrm{C}$ & -1.794523 & 1.468522 & -0.846166 \\
\hline $\mathrm{C}$ & 4.395733 & -1.343517 & -0.010728 \\
\hline $\mathrm{C}$ & -3.850003 & 1.940465 & -2.170931 \\
\hline $\mathrm{C}$ & -5.027614 & 2.627756 & -2.369360 \\
\hline $\mathrm{C}$ & -5.463158 & 3.541944 & -1.433726 \\
\hline $\mathrm{C}$ & -4.715720 & 3.763470 & -0.296355 \\
\hline $\mathrm{C}$ & -3.538407 & 3.076846 & -0.103008 \\
\hline $\mathrm{C}$ & -3.089997 & 2.155941 & -1.035534 \\
\hline $\mathrm{C}$ & 6.380765 & -2.615787 & -0.818440 \\
\hline $\mathrm{C}$ & 7.621952 & -3.178731 & -0.612877 \\
\hline $\mathrm{C}$ & 8.227897 & -3.088214 & 0.622443 \\
\hline $\mathrm{C}$ & 7.585548 & -2.430027 & 1.649757 \\
\hline $\mathrm{C}$ & 6.345160 & -1.866242 & 1.441966 \\
\hline $\mathrm{C}$ & 5.727023 & -1.953342 & 0.206295 \\
\hline $\mathrm{H}$ & 1.905190 & -5.116361 & -0.706598 \\
\hline $\mathrm{H}$ & 4.338446 & -4.181534 & -0.222937 \\
\hline $\mathrm{H}$ & 6.436989 & 0.602765 & 0.415111 \\
\hline $\mathrm{H}$ & 5.507942 & 3.085432 & 0.276545 \\
\hline $\mathrm{H}$ & 0.841827 & 5.212425 & -0.932671 \\
\hline
\end{tabular}




\begin{tabular}{|c|c|c|c|}
\hline $\mathrm{H}$ & -1.614534 & 4.281584 & -1.257923 \\
\hline $\mathrm{H}$ & -2.889237 & -2.995150 & -0.654478 \\
\hline $\mathrm{H}$ & -5.604646 & 2.450736 & -3.260838 \\
\hline $\mathrm{H}$ & -6.383160 & 4.078870 & -1.590183 \\
\hline $\mathrm{H}$ & -5.050057 & 4.471423 & 0.442460 \\
\hline H & 8.118524 & -3.686177 & -1.422260 \\
\hline $\mathrm{H}$ & 9.197067 & -3.528151 & 0.783545 \\
\hline $\mathrm{H}$ & 8.049560 & -2.356888 & 2.618526 \\
\hline $\mathrm{Zn}$ & 1.308845 & 0.061055 & -0.451931 \\
\hline $\mathrm{H}$ & -2.951466 & 3.254647 & 0.782215 \\
\hline $\mathrm{H}$ & -3.507391 & 1.230475 & -2.904725 \\
\hline $\mathrm{H}$ & 5.843126 & -1.353657 & 2.245402 \\
\hline $\mathrm{H}$ & 5.910176 & -2.683727 & -1.784995 \\
\hline $\mathrm{C}$ & -0.668666 & -4.384011 & -0.896137 \\
\hline $\mathrm{C}$ & -0.545782 & -5.330401 & 0.107867 \\
\hline $\mathrm{C}$ & -1.388951 & -4.715487 & -2.032148 \\
\hline $\mathrm{C}$ & -1.127227 & -6.573203 & -0.018982 \\
\hline $\mathrm{H}$ & 0.009628 & -5.083389 & 0.997057 \\
\hline $\mathrm{C}$ & -1.967378 & -5.959068 & -2.163166 \\
\hline $\mathrm{H}$ & -1.488690 & -3.987597 & -2.819791 \\
\hline $\mathrm{C}$ & -1.839429 & -6.891952 & -1.155919 \\
\hline $\mathrm{H}$ & -1.027361 & -7.292867 & 0.775499 \\
\hline $\mathrm{H}$ & -2.518115 & -6.200396 & -3.056200 \\
\hline $\mathrm{H}$ & -2.293526 & -7.862762 & -1.255808 \\
\hline $\mathrm{C}$ & 3.313183 & 4.515216 & -0.264463 \\
\hline $\mathrm{C}$ & 4.267240 & 4.887867 & -1.196641 \\
\hline $\mathrm{C}$ & 2.931581 & 5.434543 & 0.698325 \\
\hline $\mathrm{C}$ & 4.825347 & 6.147403 & -1.168161 \\
\hline $\mathrm{H}$ & 4.565773 & 4.181631 & -1.953124 \\
\hline $\mathrm{C}$ & 3.491861 & 6.693100 & 0.730965 \\
\hline $\mathrm{H}$ & 2.193058 & 5.152108 & 1.429705 \\
\hline $\mathrm{C}$ & 4.440134 & 7.053793 & -0.203010 \\
\hline $\mathrm{H}$ & 5.560693 & 6.422276 & -1.904953 \\
\hline $\mathrm{H}$ & 3.188576 & 7.392788 & 1.490955 \\
\hline $\mathrm{H}$ & 4.876857 & 8.037416 & -0.179014 \\
\hline $\mathrm{C}$ & -4.311582 & -0.583935 & -0.559158 \\
\hline $\mathrm{C}$ & -4.899647 & 0.076877 & 0.549393 \\
\hline $\mathrm{C}$ & -5.110053 & -1.011422 & -1.582047 \\
\hline $\mathrm{C}$ & -4.207349 & 0.395878 & 1.746946 \\
\hline $\mathrm{C}$ & -6.258215 & 0.448971 & 0.456078 \\
\hline $\mathrm{C}$ & -6.477028 & -0.733538 & -1.616512 \\
\hline $\mathrm{H}$ & -4.653175 & -1.528798 & -2.408547 \\
\hline $\mathrm{C}$ & -4.806894 & 1.175072 & 2.693234 \\
\hline $\mathrm{C}$ & -6.839011 & 1.240046 & 1.462189 \\
\hline $\mathrm{C}$ & -7.029767 & 0.023179 & -0.637305 \\
\hline $\mathrm{H}$ & -7.071684 & -1.081126 & -2.443577 \\
\hline
\end{tabular}




$\begin{array}{lrrr}\mathrm{C} & -6.119016 & 1.630544 & 2.541171 \\ \mathrm{H} & -4.269456 & 1.396397 & 3.599777 \\ \mathrm{H} & -7.871372 & 1.528790 & 1.354741 \\ \mathrm{H} & -8.069162 & 0.303924 & -0.673719 \\ \mathrm{H} & -6.562746 & 2.244128 & 3.305807 \\ \mathrm{C} & -2.907639 & -0.193412 & 2.095226 \\ \mathrm{C} & -1.830142 & 0.521951 & 2.402967 \\ \mathrm{C} & -2.864364 & -1.671695 & 2.256881 \\ \mathrm{C} & -0.556180 & -0.097652 & 2.764898 \\ \mathrm{H} & -1.828034 & 1.597325 & 2.337974 \\ \mathrm{C} & -1.569562 & -2.292564 & 2.568719 \\ \mathrm{C} & -0.495830 & -1.563602 & 2.818218 \\ \mathrm{H} & -1.567738 & -3.368396 & 2.609531 \\ \mathrm{H} & 0.458229 & -1.995464 & 3.068915 \\ \mathrm{O} & -3.863728 & -2.337245 & 2.194392 \\ \mathrm{O} & 0.424189 & 0.570733 & 2.986858\end{array}$

1ß-ZnB CT1 equilibrium geometry optimized at TD-mpwb1k/def2-SVP level/CPCM

$\begin{array}{lrrr}\mathrm{C} & 1.320531 & -2.928800 & -0.694662 \\ \mathrm{C} & 2.227659 & -4.045653 & -0.737008 \\ \mathrm{C} & 3.450973 & -3.556244 & -0.443105 \\ \mathrm{C} & 3.294110 & -2.137205 & -0.264947 \\ \mathrm{~N} & 1.980145 & -1.802383 & -0.424450 \\ \mathrm{C} & -0.085360 & -3.043409 & -0.886558 \\ \mathrm{C} & 4.229017 & 0.152813 & 0.077631 \\ \mathrm{C} & 5.334627 & 1.034113 & 0.323759 \\ \mathrm{C} & 4.846061 & 2.293299 & 0.231888 \\ \mathrm{C} & 3.452129 & 2.167126 & -0.088514 \\ \mathrm{~N} & 3.118903 & 0.852971 & -0.159179 \\ \mathrm{C} & 1.193621 & 3.103193 & -0.603042 \\ \mathrm{C} & 0.379502 & 4.189056 & -1.059984 \\ \mathrm{C} & -0.864839 & 3.686920 & -1.235362 \\ \mathrm{C} & -0.801987 & 2.296410 & -0.881758 \\ \mathrm{~N} & 0.465596 & 1.977537 & -0.524831 \\ \mathrm{C} & -1.829598 & 0.013832 & -0.829930 \\ \mathrm{C} & -2.949123 & -0.919389 & -0.706226 \\ \mathrm{C} & -2.405572 & -2.149788 & -0.820021 \\ \mathrm{C} & -0.982925 & -1.985282 & -0.891092 \\ \mathrm{~N} & -0.672339 & -0.657992 & -0.871238 \\ \mathrm{C} & 2.579775 & 3.227761 & -0.321080 \\ \mathrm{C} & -1.906919 & 1.430087 & -0.924861 \\ \mathrm{C} & 4.333635 & -1.265944 & 0.017788 \\ \mathrm{C} & -4.057785 & 1.752382 & -2.158202 \\ \mathrm{C} & -5.257029 & 2.419377 & -2.331219\end{array}$




\begin{tabular}{|c|c|c|c|}
\hline C & 593 & 574 & \\
\hline 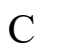 & & & \\
\hline & .602319 & 913 & \\
\hline & -3.212351 & & -1 \\
\hline & 04 & -2.4 & -0 . \\
\hline & 7.661653 & & -0.5 \\
\hline & 8.222124 & -2.8 & \\
\hline & 7.51 & -2.3 & \\
\hline 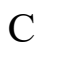 & 6.2 & -1.7 & \\
\hline 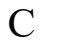 & 5.6 & -1.8 & \\
\hline 2 & & & \\
\hline $\mathrm{H}$ & 4.3 & -4.1 & -0 . \\
\hline & 6.3 & & \\
\hline $\mathrm{H}$ & 5.381779 & & \\
\hline 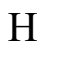 & 0.7 & & \\
\hline H & -1.7 & & \\
\hline $\mathrm{H}$ & -2.9 & -3. & \\
\hline $\mathrm{H}$ & -5.9 & & \\
\hline $\mathrm{H}$ & -6.5 & & -1 . \\
\hline 1 & -5.1 & & \\
\hline H & 8.2 & -3.3 & -1 . \\
\hline$H$ & 9.2 & -3.3 & \\
\hline $\mathrm{H}$ & 7.9 & -2.2 & 63 \\
\hline $\mathrm{Zn}$ & & & \\
\hline$U$ & -2.9 & & \\
\hline $\mathrm{H}$ & -3.7 & & 21 \\
\hline $\mathrm{H}$ & 5.7 & & \\
\hline$H$ & 5.9 & -2. & \\
\hline $\mathrm{C}$ & -0.6 & -4. & -1 \\
\hline$C$ & -0.4 & -5. & -0 \\
\hline G & -1.3 & -4.7 & -2 \\
\hline $\mathrm{C}$ & -1.0 & -6.6 & -0 . \\
\hline $\mathrm{H}$ & 0.0 & & \\
\hline 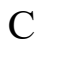 & -1.8 & -6.0 & 59 \\
\hline $\mathrm{H}$ & -1.4 & -4 & \\
\hline 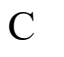 & -1.72 & -6.9 & -1 \\
\hline 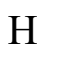 & -0.90 & -7.3 & \\
\hline 11 & -2.43 & -6.2 & 936 \\
\hline I & -2.144497 & -7.9 & 3106 \\
\hline $\mathrm{C}$ & 3.1 & 4.5 & -0.2 \\
\hline $\mathrm{C}$ & 4.162522 & 4.95 & -1.1 \\
\hline $\mathrm{C}$ & 2.63 & & \\
\hline $\mathrm{C}$ & 4.676 & 6.23 & -1.1 \\
\hline 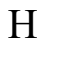 & 4.544880 & 4.219387 & -1.883399 \\
\hline $\mathrm{C}$ & 3.162652 & 6.833557 & 0.589109 \\
\hline 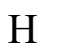 & 1.840220 & 5.281662 & 1.256408 \\
\hline
\end{tabular}




$\begin{array}{lrrc}\mathrm{C} & 4.181244 & 7.180623 & -0.284879 \\ \mathrm{H} & 5.467000 & 6.507493 & -1.866550 \\ \mathrm{H} & 2.773404 & 7.564683 & 1.290166 \\ \mathrm{H} & 4.587547 & 8.186874 & -0.274920 \\ \mathrm{C} & -4.356637 & -0.648804 & -0.386255 \\ \mathrm{C} & -4.730583 & 0.091996 & 0.774966 \\ \mathrm{C} & -5.322883 & -1.077714 & -1.261614 \\ \mathrm{C} & -3.843170 & 0.386154 & 1.855955 \\ \mathrm{C} & -6.063728 & 0.570344 & 0.847485 \\ \mathrm{C} & -6.668252 & -0.715463 & -1.102957 \\ \mathrm{H} & -5.020518 & -1.655057 & -2.129926 \\ \mathrm{C} & -4.240275 & 1.281007 & 2.818298 \\ \mathrm{C} & -6.429362 & 1.470947 & 1.871167 \\ \mathrm{C} & -7.018921 & 0.137128 & -0.098871 \\ \mathrm{H} & -7.409391 & -1.067962 & -1.812823 \\ \mathrm{C} & -5.520258 & 1.858768 & 2.809554 \\ \mathrm{H} & -3.562617 & 1.495399 & 3.639069 \\ \mathrm{H} & -7.448176 & 1.845818 & 1.894751 \\ \mathrm{H} & -8.040850 & 0.491337 & -0.002070 \\ \mathrm{H} & -5.797125 & 2.562403 & 3.588067 \\ \mathrm{C} & -2.580763 & -0.353730 & 2.074065 \\ \mathrm{C} & -1.356355 & 0.237654 & 2.095739 \\ \mathrm{C} & -2.700930 & -1.794699 & 2.330593 \\ \mathrm{C} & -0.147208 & -0.513624 & 2.227469 \\ \mathrm{H} & -1.247000 & 1.295954 & 1.874630 \\ \mathrm{C} & -1.473707 & -2.491319 & 2.658774 \\ \mathrm{C} & -0.263310 & -1.884138 & 2.614992 \\ \mathrm{H} & -1.576097 & -3.544790 & 2.899020 \\ \mathrm{H} & 0.657332 & -2.428289 & 2.802181 \\ \mathrm{O} & -3.777023 & -2.380395 & 2.258292 \\ \mathrm{O} & 0.979227 & 0.001591 & 1.936593\end{array}$

1ß-ZnB CT2 equilibrium geometry optimized at TD-mpwb1k/def2-SVP level/CPCM

$\begin{array}{lrrr}\mathrm{C} & 1.295752 & -2.922245 & -0.698185 \\ \mathrm{C} & 2.198269 & -4.061655 & -0.693580 \\ \mathrm{C} & 3.414171 & -3.586505 & -0.385798 \\ \mathrm{C} & 3.272179 & -2.147385 & -0.236868 \\ \mathrm{~N} & 1.991165 & -1.791491 & -0.432489 \\ \mathrm{C} & -0.074319 & -3.020641 & -0.918719 \\ \mathrm{C} & 4.249971 & 0.100826 & 0.078461 \\ \mathrm{C} & 5.385991 & 0.988712 & 0.269496 \\ \mathrm{C} & 4.916645 & 2.240496 & 0.159741 \\ \mathrm{C} & 3.491013 & 2.127644 & -0.108060 \\ \mathrm{~N} & 3.136008 & 0.827879 & -0.130580\end{array}$




\begin{tabular}{|c|c|c|c|}
\hline C & 100 & 00720 & -0 \\
\hline & 432599 & & - 096 \\
\hline & .808631 & 270 & 749 \\
\hline & -0.744914 & 2.317615 & -0.8 \\
\hline & 591 & 1.977529 & 002 \\
\hline & -1.790101 & 0.073469 & -0 \\
\hline C & -2.931064 & 7017 & 287 \\
\hline 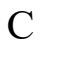 & -2.396023 & -2. & 299 \\
\hline $\mathrm{C}$ & -0.963345 & -1. & \\
\hline N & -0.637580 & -0.6 & 592 \\
\hline C & 2.64 & & \\
\hline C & -1.862914 & 08 & -0 \\
\hline $\mathrm{C}$ & 4.34 & -1.2 & \\
\hline $\mathrm{C}$ & -3.987360 & 07 & 109 \\
\hline C & -5.17 & 2.6 & \\
\hline C & -5.5 & & \\
\hline $\mathrm{C}$ & -4.758489 & 26 & -0 \\
\hline $\mathrm{C}$ & -3.568927 & & \\
\hline $\mathrm{C}$ & -3.169028 & 60 & \\
\hline C & 6.406139 & -2.4 & \\
\hline C & 899 & -3.0 & 952 \\
\hline C & 8.1 & -3.0 & \\
\hline C & 7.4 & -2. & \\
\hline $\mathrm{C}$ & 6.230200 & -1.8 & \\
\hline $\mathrm{C}$ & 5.6 & -1. & \\
\hline $\mathrm{H}$ & 1.916500 & $-5 .($ & 327 \\
\hline H & 4.3 & -4.1 & 47 \\
\hline $\mathrm{H}$ & 6.402492 & 0.6 & \\
\hline H & 5.465726 & 3.1 & \\
\hline $\mathrm{H}$ & 0.777669 & 5.2 & 92 \\
\hline H & -1.69 & 4.2 & \\
\hline 11 & -2.921729 & $-3 .($ & 337 \\
\hline $\mathrm{H}$ & -5.804814 & 99 & \\
\hline $\mathrm{H}$ & -6.497116 & 4.1 & 35 \\
\hline $\mathrm{H}$ & -5.0 & 4.4 & \\
\hline $\mathrm{H}$ & 8.208272 & -3.4 & -1 \\
\hline-1 & 9.169616 & -3.4 & \\
\hline $\mathrm{H}$ & 7.892760 & -2.3 & 33 \\
\hline $\mathrm{Zn}$ & 1.211097 & 4497 & 4280 \\
\hline $\mathrm{H}$ & -2.940455 & 3.2 & \\
\hline $\mathbf{T}$ & -3.682126 & 1.250651 & 891 \\
\hline 11 & 5.668801 & -1.4 & 905 \\
\hline $\mathrm{H}$ & 5.989352 & -2.510700 & -1.726531 \\
\hline 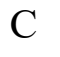 & -0.662523 & -4.368846 & -1.10 \\
\hline $\mathrm{C}$ & -0.604599 & -5.315143 & -0.08 \\
\hline 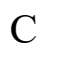 & -1.302552 & -4.703067 & -2.295638 \\
\hline
\end{tabular}




\begin{tabular}{|c|c|c|c|}
\hline & 66808 & -6.569363 & \\
\hline & -0.124201 & -5.053407 & \\
\hline & -1.864428 & -5.957296 & \\
\hline & .353943 & -3.970764 & \\
\hline & -1.797089 & -6.893675 & -1. \\
\hline & -1.119067 & -7.294077 & 0.5 \\
\hline & -2.356071 & -6.204879 & -3. \\
\hline & -2.239607 & -7.8 & -1 . \\
\hline & 3.2 & 4.5 & -0.2 \\
\hline & 4.180046 & 4.9 & -1.2 \\
\hline & 2.8 & & \\
\hline & 4.726106 & 6.2 & -1. \\
\hline & 4.4 & & -2 \\
\hline & 3.388839 & 59 & \\
\hline & 2.1 & 5.2 & \\
\hline & 4.3 & 7.1 & -0.2 \\
\hline & 5.4 & 6.5 & -2 \\
\hline & 3.0 & & \\
\hline & 4.7 & 8.1 & -0.2 \\
\hline & -4.3 & -0. & \\
\hline & $-4.7^{\prime}$ & 0.0 & 0.7 \\
\hline & -5.2 & -0.9 & \\
\hline & -3.9 & & \\
\hline & & & \\
\hline & -6.6 & -0. & -1 \\
\hline & -4.9 & -1 & -2.2 \\
\hline & -4.4 & & \\
\hline & -6.5 & & \\
\hline & -7.0 & 01 & -0.2 \\
\hline & -7.3 & -0. & -2. \\
\hline & -5.6 & 1.7 & 69 \\
\hline & -3.7 & 1.3 & \\
\hline & -7.5 & & \\
\hline & -8.0 & 0.5 & -0.2 \\
\hline & -6.0 & & \\
\hline & -2.697782 & -0.4 & 32 \\
\hline & $-1.4^{\prime}$ & & \\
\hline & -2.8 & -1.8 & 374 \\
\hline & -0.258493 & -0.5 & \\
\hline H & -1.3 & 1.2 & 08 \\
\hline 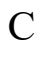 & -1.580190 & -2.567249 & 5761 \\
\hline 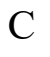 & -0.3 & -1.9 & 2.50 \\
\hline & -1.672055 & -3.632313 & 2.744922 \\
\hline & 0.556373 & -2.513735 & 2.629533 \\
\hline $\mathrm{O}$ & -3.898885 & -2.444476 & 2.239375 \\
\hline & 0.858820 & -0.026510 & 1.933815 \\
\hline
\end{tabular}


1ß-ZnB LE1 equilibrium geometry optimized at TD-mpwb1k/def2-SVP level/CPCM

$\begin{array}{lrrr}\mathrm{C} & 1.391717 & -2.917923 & -0.621589 \\ \mathrm{C} & 2.327155 & -4.010138 & -0.645458 \\ \mathrm{C} & 3.556084 & -3.473878 & -0.481914 \\ \mathrm{C} & 3.379481 & -2.050264 & -0.375112 \\ \mathrm{~N} & 2.059510 & -1.748056 & -0.480606 \\ \mathrm{C} & 0.003631 & -3.068717 & -0.730270 \\ \mathrm{C} & 4.274750 & 0.247152 & 0.018771 \\ \mathrm{C} & 5.337610 & 1.155556 & 0.314385 \\ \mathrm{C} & 4.790837 & 2.400920 & 0.333429 \\ \mathrm{C} & 3.408168 & 2.243549 & 0.016042 \\ \mathrm{~N} & 3.121579 & 0.930087 & -0.152549 \\ \mathrm{C} & 1.122195 & 3.138175 & -0.451625 \\ \mathrm{C} & 0.283379 & 4.218221 & -0.882767 \\ \mathrm{C} & -0.930362 & 3.688882 & -1.148837 \\ \mathrm{C} & -0.850280 & 2.280921 & -0.856647 \\ \mathrm{~N} & 0.414612 & 1.977544 & -0.462150 \\ \mathrm{C} & -1.834397 & -0.021322 & -0.866144 \\ \mathrm{C} & -2.917950 & -0.959127 & -0.683901 \\ \mathrm{C} & -2.337753 & -2.201472 & -0.671835 \\ \mathrm{C} & -0.938352 & -2.014520 & -0.779679 \\ \mathrm{~N} & -0.656198 & -0.686560 & -0.870861 \\ \mathrm{C} & 2.482929 & 3.296460 & -0.146976 \\ \mathrm{C} & -1.933930 & 1.396143 & -0.981536 \\ \mathrm{C} & 4.421252 & -1.152268 & -0.128348 \\ \mathrm{C} & -3.995731 & 1.576159 & -2.370727 \\ \mathrm{C} & -5.202117 & 2.178932 & -2.677393 \\ \mathrm{C} & -5.683873 & 3.217265 & -1.895440 \\ \mathrm{C} & -4.951318 & 3.646481 & -0.799605 \\ \mathrm{C} & -3.742942 & 3.047604 & -0.496503 \\ \mathrm{C} & -3.239665 & 2.006446 & -1.280844 \\ \mathrm{C} & 6.406763 & -2.306551 & -1.102426 \\ \mathrm{C} & 7.685453 & -2.826581 & -0.995266 \\ \mathrm{C} & 8.366735 & -2.757153 & 0.209373 \\ \mathrm{C} & 7.761872 & -2.161822 & 1.305345 \\ \mathrm{C} & 6.485381 & -1.637138 & 1.197054 \\ \mathrm{H} & 5.788552 & -1.705050 & -0.008005 \\ \mathrm{H} & 2.076816 & -5.052166 & -0.779378 \\ \mathrm{H} & 6.500143 & -3.996097 & -0.430270 \\ \mathrm{H} & 0.596925 & 0.888905 & 0.482711 \\ \mathrm{H} & 5.243483 & -1.014652 \\ \mathrm{H} & -1.202328 & -1.547494\end{array}$




$\begin{array}{lrrr}\mathrm{H} & -2.847375 & -3.141359 & -0.515119 \\ \mathrm{H} & -5.770688 & 1.835794 & -3.535921 \\ \mathrm{H} & -6.632224 & 3.686897 & -2.136860 \\ \mathrm{H} & -5.327385 & 4.447006 & -0.170603 \\ \mathrm{H} & 8.153439 & -3.285890 & -1.860250 \\ \mathrm{H} & 9.368378 & -3.166294 & 0.294406 \\ \mathrm{H} & 8.286151 & -2.108498 & 2.254286 \\ \mathrm{Zn} & 1.233273 & 0.115773 & -0.305298 \\ \mathrm{H} & -3.180064 & 3.370410 & 0.373547 \\ \mathrm{H} & -3.619322 & 0.764759 & -2.986352 \\ \mathrm{H} & 6.011473 & -1.175582 & 2.057988 \\ \mathrm{H} & 5.875776 & -2.357391 & -2.048078 \\ \mathrm{C} & -0.539949 & -4.441259 & -0.746548 \\ \mathrm{C} & -0.291534 & -5.320940 & 0.306873 \\ \mathrm{C} & -1.327002 & -4.884418 & -1.809568 \\ \mathrm{C} & -0.809697 & -6.604827 & 0.296129 \\ \mathrm{H} & 0.308702 & -4.983035 & 1.146361 \\ \mathrm{C} & -1.837640 & -6.170216 & -1.824392 \\ \mathrm{H} & -1.527038 & -4.209428 & -2.636008 \\ \mathrm{C} & -1.582255 & -7.034672 & -0.770773 \\ \mathrm{H} & -0.611377 & -7.272074 & 1.128915 \\ \mathrm{H} & -2.437489 & -6.500817 & -2.666377 \\ \mathrm{H} & -1.986573 & -8.041778 & -0.781030 \\ \mathrm{C} & 2.988452 & 4.678552 & -0.025294 \\ \mathrm{C} & 4.020688 & 5.146256 & -0.838151 \\ \mathrm{C} & 2.428957 & 5.551735 & 0.907382 \\ \mathrm{C} & -7.385 \\ \mathrm{C} & 4.477093 & 6.447624 & -0.722292 \\ \mathrm{H} & 4.454877 & 4.481453 & -1.578311 \\ \mathrm{C} & 2.892235 & 6.850172 & 1.029506 \\ \mathrm{H} & 1.628264 & 5.196797 & 1.548797 \\ \mathrm{C} & 3.917201 & 7.302906 & 0.214250 \\ \mathrm{H} & 5.273071 & 6.797563 & -1.371902 \\ \mathrm{H} & 2.451148 & 7.511502 & 1.768500 \\ \mathrm{H} & 4.278855 & 8.321984 & 0.307014 \\ \mathrm{C} & -4.337210 & -0.697507 & -0.424117 \\ \mathrm{C} & -4.723368 & 0.090976 & 0.695534 \\ \mathrm{C} & -5.303994 & -1.163646 & -1.280571 \\ \mathrm{C} & -3.826788 & 0.413550 & 1.756126 \\ \mathrm{C} & -6.646836 & 0.588979 & 0.750402 \\ \mathrm{C} & -0.784035 & -1.137862 \\ \mathrm{H} & -192138 & 1.350679 & 2.689407 \\ \mathrm{H} & -1.163259 & 1.947804 & 2.658190\end{array}$




$\begin{array}{rrrr}\mathrm{H} & -3.509354 & 1.583607 & 3.500653 \\ \mathrm{H} & -7.395708 & 1.936165 & 1.755016 \\ \mathrm{H} & -8.020102 & 0.485571 & -0.107393 \\ \mathrm{H} & -5.725455 & 2.688310 & 3.406930 \\ \mathrm{C} & -2.603225 & -0.376562 & 1.992708 \\ \mathrm{C} & -1.359776 & 0.124621 & 2.026228 \\ \mathrm{C} & -2.815350 & -1.818967 & 2.332843 \\ \mathrm{C} & -0.196207 & -0.737601 & 2.190071 \\ \mathrm{H} & -1.153925 & 1.160950 & 1.774938 \\ \mathrm{C} & -1.627474 & -2.633793 & 2.657749 \\ \mathrm{C} & -0.400210 & -2.119722 & 2.639157 \\ \mathrm{H} & -1.827397 & -3.669320 & 2.914889 \\ \mathrm{H} & 0.491179 & -2.698626 & 2.859640 \\ \mathrm{O} & -3.917824 & -2.296626 & 2.391401 \\ \mathrm{O} & 0.921605 & -0.346814 & 1.893606\end{array}$

1a-Zn ground state equilibrium geometry (Franck-Condon geometry) optimized at mpwb1k/def2-SVP level/CPCM level

$\begin{array}{lrrr}\mathrm{C} & -3.615533 & -1.890164 & -0.092505 \\ \mathrm{C} & -4.557458 & -2.944393 & 0.174536 \\ \mathrm{C} & -3.840209 & -4.085266 & 0.297922 \\ \mathrm{C} & -2.464817 & -3.726901 & 0.115918 \\ \mathrm{~N} & -2.363867 & -2.400242 & -0.128692 \\ \mathrm{C} & -3.947677 & -0.535765 & -0.227057 \\ \mathrm{C} & -0.051323 & -4.314145 & 0.103420 \\ \mathrm{C} & 1.007418 & -5.266623 & 0.263410 \\ \mathrm{C} & 2.165913 & -4.593313 & 0.074495 \\ \mathrm{C} & 1.809591 & -3.230224 & -0.213903 \\ \mathrm{~N} & 0.464761 & -3.094921 & -0.175736 \\ \mathrm{C} & 2.370803 & -0.883223 & -0.770947 \\ \mathrm{C} & 3.292393 & 0.131903 & -1.201616 \\ \mathrm{C} & 2.579091 & 1.271211 & -1.351230 \\ \mathrm{C} & 1.225276 & 0.957167 & -0.997625 \\ \mathrm{~N} & 1.124696 & -0.351893 & -0.680727 \\ \mathrm{C} & -1.160231 & 1.596357 & -0.713259 \\ \mathrm{C} & -3.367346 & 1.889813 & -0.492636 \\ \mathrm{C} & -3.022754 & 0.496281 & -0.420525 \\ \mathrm{~N} & -1.681874 & 0.355587 & -0.563472 \\ \mathrm{C} & 2.722799 & -2.209364 & -0.507720 \\ \mathrm{C} & 0.193845 & 1.901955 & -0.908656 \\ \mathrm{C} & -1.401505 & -4.612425 & 0.221961 \\ \mathrm{H} & -5.626540 & -2.818483 & 0.269932 \\ \mathrm{H} & -4.202139 & -5.082862 & 0.509513 \\ \mathrm{H} & 0.873597 & -6.314379 & 0.498369 \\ \mathrm{H} & 3.174519 & -4.977139 & 0.130946\end{array}$




\begin{tabular}{|c|c|c|c|}
\hline $\mathrm{H}$ & 6105 & -0.020236 & \\
\hline & 935473 & 2.239284 & -1.673883 \\
\hline & .366851 & 3920 & 397 \\
\hline & .618944 & -1.377106 & -0.401739 \\
\hline & -5.382827 & -0.172286 & 008 \\
\hline & -5.852511 & 0.56 & 0.9 \\
\hline & -6.289096 & -0.57 & -1.0 \\
\hline & -7.193265 & 47 & 1.0 \\
\hline $\mathrm{H}$ & -5.1 & & \\
\hline & -7.630085 & -0.23 & -0.9 \\
\hline & -5.932994 & -1.1 & 758 \\
\hline $\mathrm{C}$ & -8.086068 & 0.4 & \\
\hline H & -7.5 & 1.4 & 25 \\
\hline $\mathrm{H}$ & -8.322172 & -0.5 & -1 . \\
\hline $\mathrm{H}$ & -9.1 & 0.7 & 60 \\
\hline $\mathrm{C}$ & 4.1 & -2.5 & \\
\hline $\mathrm{C}$ & $4.6^{\prime}$ & -3.4 & -1.5 \\
\hline C & 5.0 & -2.0 & \\
\hline C & 6.02 & -3.7 & -1.5 \\
\hline H & 4.00 & -3.8 & -2.2 \\
\hline C & 6.38 & -2.3 & 0.3 \\
\hline $\mathrm{H}$ & 4.62 & -1.3 & \\
\hline $\mathrm{C}$ & 6.8 & -3 & -0 \\
\hline $\mathrm{H}$ & 6.4 & -4.3 & -2. \\
\hline $\mathrm{H}$ & 7.0 & -1.8 & \\
\hline $\mathrm{H}$ & 7.94 & -3. & -0 \\
\hline $\mathrm{C}$ & 0.56 & & -1. \\
\hline 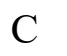 & 1.44 & 4.0 & -0.2 \\
\hline $\mathrm{C}$ & 0.097 & 3.9 & -2.2 \\
\hline $\mathrm{C}$ & 1.96 & 3.5 & \\
\hline $\mathrm{C}$ & 1.85 & 5.3 & -0 \\
\hline $\mathrm{C}$ & 0.462170 & 5.2 & -2.5 \\
\hline $\mathrm{H}$ & -0.55 & 3.3 & -2 \\
\hline $\mathrm{C}$ & 2.898 & 4.2 & \\
\hline $\mathrm{C}$ & 2.798 & 6.0 & \\
\hline $\mathrm{C}$ & 1.340 & 5.9 & -1.7 \\
\hline $\mathrm{H}$ & 0.066759 & 5.7 & -3.4 \\
\hline $\mathrm{C}$ & 3.329586 & 5.5 & 1.2 \\
\hline $\mathrm{H}$ & 3.277525 & 3.8 & \\
\hline $\mathrm{H}$ & 3.094 & 7.0 & -0.1 \\
\hline $\mathrm{H}$ & 1.665439 & 6.9 & -2.0 \\
\hline $\mathrm{H}$ & 4.060408 & 6.043441 & 1.879565 \\
\hline $\mathrm{C}$ & 1.518090 & 2.243656 & 1.592713 \\
\hline $\mathrm{C}$ & 2.353 & 1.23 & 1.89 \\
\hline $\mathrm{C}$ & 0.092147 & 2.160463 & 2.013483 \\
\hline$C$ & 1.880056 & -0.031945 & 2.445536 \\
\hline
\end{tabular}




$\begin{array}{lrrr}\mathrm{C} & -0.397899 & 0.853717 & 2.486721 \\ \mathrm{C} & 0.434808 & -0.160803 & 2.711617 \\ \mathrm{H} & 0.099984 & -1.121791 & 3.090572 \\ \mathrm{H} & -1.651833 & -5.645887 & 0.436604 \\ \mathrm{C} & -2.211337 & 2.571953 & -0.649100 \\ \mathrm{H} & -2.078233 & 3.641855 & -0.710076 \\ \mathrm{H} & -1.464015 & 0.791944 & 2.682983 \\ \mathrm{O} & -0.618454 & 3.133533 & 2.016096 \\ \mathrm{O} & 2.633327 & -0.954666 & 2.652323 \\ \mathrm{H} & 3.410091 & 1.290730 & 1.644602\end{array}$

1a-Zn CT1 equilibrium geometry optimized at TD-mpwb1k/def2-SVP level/CPCM level

$\begin{array}{lrrr}\mathrm{C} & -3.244894 & -2.166226 & 0.034248 \\ \mathrm{C} & -4.041551 & -3.277777 & 0.487635 \\ \mathrm{C} & -3.178587 & -4.280175 & 0.766686 \\ \mathrm{C} & -1.864255 & -3.778005 & 0.487410 \\ \mathrm{~N} & -1.951700 & -2.482098 & 0.056496 \\ \mathrm{C} & -3.779781 & -0.901644 & -0.367608 \\ \mathrm{C} & 0.603918 & -4.080927 & 0.294980 \\ \mathrm{C} & 1.766514 & -4.911084 & 0.400399 \\ \mathrm{C} & 2.818096 & -4.139464 & 0.037444 \\ \mathrm{C} & 2.282888 & -2.846864 & -0.289352 \\ \mathrm{~N} & 0.930801 & -2.857850 & -0.123658 \\ \mathrm{C} & 2.511783 & -0.455361 & -0.944621 \\ \mathrm{C} & 3.319745 & 0.689569 & -1.268629 \\ \mathrm{C} & 2.472490 & 1.735030 & -1.387785 \\ \mathrm{C} & 1.151375 & 1.216081 & -1.165846 \\ \mathrm{~N} & 1.218889 & -0.121503 & -0.926307 \\ \mathrm{C} & -1.332863 & 1.485512 & -1.122486 \\ \mathrm{C} & -3.565611 & 1.468505 & -1.135700 \\ \mathrm{C} & -3.027782 & 0.177356 & -0.776330 \\ \mathrm{~N} & -1.658693 & 0.229430 & -0.841842 \\ \mathrm{C} & 3.036831 & -1.746822 & -0.665383 \\ \mathrm{C} & 0.004161 & 1.988319 & -1.145670 \\ \mathrm{C} & -0.707160 & -4.504274 & 0.601004 \\ \mathrm{H} & -5.117332 & -3.282491 & 0.583071 \\ \mathrm{H} & -3.402528 & -5.275234 & 1.127381 \\ \mathrm{H} & 1.772062 & -5.944865 & 0.718825 \\ \mathrm{H} & 3.864280 & -4.408074 & 0.003554 \\ \mathrm{H} & 4.393478 & 0.684390 & -1.388008 \\ \mathrm{H} & 2.707271 & 2.762757 & -1.626256 \\ \mathrm{H} & -4.615444 & 1.711543 & -1.208831 \\ \mathrm{Zn} & -0.342120 & -1.227668 & -0.210815 \\ \mathrm{C} & -5.249581 & -0.736564 & -0.284347\end{array}$




\begin{tabular}{|c|c|c|c|}
\hline & 00990 & 763 & \\
\hline & 099680 & -1.477732 & -1101079 \\
\hline & -7.174180 & 0.320269 & \\
\hline & -5.141149 & .738854 & .266310 \\
\hline & -7.471750 & -1.315324 & 6121 \\
\hline & -5.678174 & -2.178974 & -1 . \\
\hline & -8.012198 & -0.417506 & -0. \\
\hline & -7.590174 & 223 & 870 \\
\hline & -8.1 & -1.8 & -1.6 \\
\hline & -9.0 & -0.29 & $-0 .($ \\
\hline & 4.5 & -1.9 & -0.7 \\
\hline & 730 & -2.5 & 075 \\
\hline & 5.2 & -1.3 & 134 \\
\hline & 209 & -2.7 & $-1 . \varepsilon$ \\
\hline & 4.4 & -3.0 & -2.5 \\
\hline & 6.6 & -1.5 & \\
\hline & 277 & -0.8 & 88 \\
\hline & $7.2^{\prime}$ & -2.1 & -0.8 \\
\hline & 6.9 & -3.2 & -2.6 \\
\hline & 7.2 & -1.0 & \\
\hline & 503 & -2.2 & -0.8 \\
\hline & 0.19 & 3.4 & -1.0 \\
\hline & 0.7 & 4.0 & \\
\hline & -0.1 & 4.2 & -2 . \\
\hline & 1.1 & 3.3 & \\
\hline & 962 & 5.4 & 0.0 \\
\hline & 0.0 & 5.5 & -2. \\
\hline & -0.5 & 3.7 & $-3 .($ \\
\hline & 1.7 & 4.10 & 2.2 \\
\hline & 1.62 & 6.1 & 1.0 \\
\hline$C$ & 0.62 & 6.2 & -1.1 \\
\hline & -0.232682 & 6.1 & -3. \\
\hline & 2.0 & 5.4 & 2.2 \\
\hline & 2.0 & 3.5 & \\
\hline & 1.77 & 7.2 & 0.9 \\
\hline $\mathrm{H}$ & 0.8 & 7.2 & -1.1 \\
\hline & 2.499911 & 5.93 & \\
\hline $\mathrm{C}$ & 0.92 & 1.94 & 1.6 \\
\hline & 1.974705 & 1.13 & \\
\hline C & -0.4 & 1.4 & 390 \\
\hline & 1.832648 & -0.265341 & 2.255939 \\
\hline & -0.591642 & 0.062971 & 2.057642 \\
\hline & 0.477557 & -0.754046 & 2.320009 \\
\hline & 0.339094 & -1.789086 & 2.619728 \\
\hline 11 & -0.809948 & -5.526973 & 0.948192 \\
\hline & -2.515549 & 2.287912 & -1.318693 \\
\hline
\end{tabular}




$\begin{array}{rrrr}\mathrm{H} & -2.533211 & 3.341305 & -1.551403 \\ \mathrm{H} & -1.613395 & -0.293317 & 2.166229 \\ \mathrm{O} & -1.412177 & 2.194772 & 1.507565 \\ \mathrm{O} & 2.813311 & -0.991330 & 2.463892 \\ \mathrm{H} & 2.992058 & 1.510547 & 1.849953\end{array}$

1a-Zn LE1 equilibrium geometry optimized at TD-mpwb1k/def2-SVP level/CPCM level

$\begin{array}{lrrc}\mathrm{C} & -3.644807 & -1.850387 & -0.097480 \\ \mathrm{C} & -4.592628 & -2.892567 & 0.175783 \\ \mathrm{C} & -3.883698 & -4.043756 & 0.291026 \\ \mathrm{C} & -2.507884 & -3.697880 & 0.099588 \\ \mathrm{~N} & -2.393007 & -2.371630 & -0.140964 \\ \mathrm{C} & -3.964924 & -0.486525 & -0.230824 \\ \mathrm{C} & -0.096041 & -4.320337 & 0.057295 \\ \mathrm{C} & 0.957465 & -5.282487 & 0.218967 \\ \mathrm{C} & 2.120958 & -4.618682 & 0.026885 \\ \mathrm{C} & 1.773671 & -3.254051 & -0.270472 \\ \mathrm{~N} & 0.429016 & -3.105858 & -0.233492 \\ \mathrm{C} & 2.351249 & -0.897273 & -0.828027 \\ \mathrm{C} & 3.279514 & 0.102316 & -1.265975 \\ \mathrm{C} & 2.576879 & 1.253487 & -1.407908 \\ \mathrm{C} & 1.223544 & 0.955687 & -1.041673 \\ \mathrm{~N} & 1.107236 & -0.354043 & -0.732533 \\ \mathrm{C} & -1.160798 & 1.624244 & -0.742202 \\ \mathrm{C} & -3.365829 & 1.939258 & -0.502934 \\ \mathrm{C} & -3.032723 & 0.542082 & -0.435343 \\ \mathrm{~N} & -1.692520 & 0.387286 & -0.593174 \\ \mathrm{C} & 2.694010 & -2.233252 & -0.560369 \\ \mathrm{C} & 0.197692 & 1.917803 & -0.947068 \\ \mathrm{C} & -1.448999 & -4.601682 & 0.191197 \\ \mathrm{H} & -5.659265 & -2.757412 & 0.282570 \\ \mathrm{H} & -4.253584 & -5.038252 & 0.502696 \\ \mathrm{H} & 0.815243 & -6.327049 & 0.462157 \\ \mathrm{H} & 3.126655 & -5.008813 & 0.087463 \\ \mathrm{H} & 4.329308 & -0.062142 & -1.462249 \\ \mathrm{H} & 2.941304 & 2.216353 & -1.736341 \\ \mathrm{H} & -4.360356 & 2.352954 & -0.424098 \\ \mathrm{Zn} & -0.636330 & -1.359998 & -0.411715 \\ \mathrm{C} & -5.392614 & -0.111627 & -0.114402 \\ \mathrm{C} & -5.840060 & 0.665417 & 0.951685 \\ \mathrm{C} & -6.317015 & -0.539467 & -1.064427 \\ \mathrm{C} & -7.177165 & 1.006844 & 1.064136 \\ \mathrm{H} & -5.129163 & 0.996257 & 1.702725 \\ \mathrm{C} & -7.653393 & -0.193836 & -0.954107\end{array}$




\begin{tabular}{|c|c|c|c|}
\hline & 5.977875 & -1.142692 & -1.901047 \\
\hline & -8.087472 & 0.579572 & 0110732 \\
\hline & -7.509698 & 1.607539 & 1.904705 \\
\hline & -8.359366 & -0.528863 & -1.707338 \\
\hline & -9.135222 & 0.848710 & 0.197945 \\
\hline & 4.132082 & -2.574860 & 8794 \\
\hline & 4.666906 & -3.463221 & -1.4 \\
\hline & 4.975930 & -2.000576 & 0.3 \\
\hline & 6.01 & -3.76 & -1.4 \\
\hline & 4.015686 & -3.910650 & 3120 \\
\hline & 6.32 & -2.307233 & \\
\hline & 503 & -1.3 & 309 \\
\hline & 6.8 & -3.1 & -0.5 \\
\hline & 6.4 & -4.4 & 240 \\
\hline & 6.9 & -1.8 & 751 \\
\hline & 7.9 & -3. & -0 . \\
\hline & $0.5 \mathrm{~S}$ & 726 & -1. \\
\hline & 1.5 & 3.9 & 569 \\
\hline & 0.1 & 300 & -2. \\
\hline & 2.0 & 63 & \\
\hline & 1.9 & 316 & -0.6 \\
\hline & 0.5 & 5.3 & -2.5 \\
\hline & -0.5 & 698 & -2 \\
\hline & 3.0 & 47 & \\
\hline & 2.9 & 91 & 0.1 \\
\hline & 1.4 & 91 & -1. \\
\hline & 0.1 & 34 & 104 \\
\hline & 3.52 & 5.3 & 1.2 \\
\hline & 3.4145 & 549 & 779 \\
\hline & 3.324486 & 3450 & 508 \\
\hline & 1.82 & 6.9 & -1.9 \\
\hline & 4.306264 & 5.8 & 252 \\
\hline & 1.53 & 2.1 & 62 \\
\hline & 2.32 & 1.1 & 80 \\
\hline & 0.1 & 2.173224 & 542 \\
\hline & 1.8 & -0.0 & 474 \\
\hline & -0.415727 & 0.912226 & 929 \\
\hline $\mathrm{C}$ & 0.378915 & -0.1 & 795 \\
\hline & 0.004692 & -1.058710 & 3372 \\
\hline 20 & -1.7 & -5.6 & 909 \\
\hline & -2.205053 & 2.611066 & -0.661932 \\
\hline 20 & -2.061214 & 3.680078 & -0.706288 \\
\hline $\mathrm{H}$ & -1.479379 & 0.901427 & 2.782230 \\
\hline 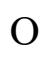 & -0.569953 & 3.171858 & 1.971562 \\
\hline $\mathrm{O}$ & 2.545967 & -1.020759 & 2.776296 \\
\hline 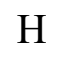 & 3.378057 & 1.140849 & 1.638787 \\
\hline
\end{tabular}




\section{References}

1. DiMagno, S. G.; Lin, V. S.-Y.; Therien, M. J., Catalytic Conversion of Simple Haloporphyrins into Alkyl-, Aryl-, Pyridyl-, and Vinyl-Substituted Porphyrins. J. Am. Chem. Soc. 1993, 115, 2513-2515.

2. Samuels, E.; Shuttleworth R.; Stevens, T. S., Halogenation of Porphin and Octaethylporphin. J. Chem. Soc. C 1968, 145-147.

3. Callot, H. J., Bromination of Meta-Tetraphenylporphine - Preparation of Alkyl Derivatives and Polycyanoporphines. Bull. Soc. Chim. Fr. 1974, 1492-1496.

4. Callot, H. J., Bromination of Mesotetraphenylporphine - Structure and Reactivity of Products. Tetrahedron Lett. 1973, 4987-4990.

5. $\quad$ Crossley, M. J.; Harding, M. M.; Sternhell, S., Tautomerism in 2-Substituted 5,10,15,20Tetraphenylporphyrins. J. Am. Chem. Soc. 1986, 108, 3608-3613.

6. Hyslop, A. G.; Kellett, M. A.; lovine, P. M.; Therien, M. J., Suzuki Porphyrins: New Synthons for the Fabrication of Porphyrin-Containing Supramolecular Assemblies. J. Am. Chem. Soc. 1998, 120, 12676-12677.

7. lovine, P. M.; Kellett, M. A.; Redmore, N. P.; Therien, M. J., Syntheses and ${ }^{1} \mathrm{H}$ NMR Spectroscopy of Rigid, Cofacially Aligned, Porphyrin-Bridge-Quinone Systems in Which the Interplanar Separations between the Porphyrin, Aromatic Bridge, and Quinone Are Less Than the Sum of Their Respective van der Waals Radii. J. Am. Chem. Soc. 2000, 122, 8717-8727.

8. Zheng, J.; Kang, Y. K.; Therien, M. J.; Beratan, D. N., Generalized Mulliken-Hush Analysis of Electronic Coupling Interactions in Compressed m-Stacked Porphyrin-Bridge-Quinone Systems. J. Am. Chem. Soc. 2005, 127, 11303-11310.

9. Kato, T.; Tachiya, M., Effect of the Molecular Shapes of the Donor and the Acceptor on Electron-Transfer Rates. Chem. Phys. Lett. 1995, 241, 463-468.

10. Marcus, R. A., On the Theory of Oxidation-Reduction Reactions Involving Electron Transfer: I. J. Chem. Phys. 1956, 24, 966-978.

11. Levich, V. G., Present State of the Theory of Oxidation-Reduction in Solution (Bulk and Electrode Reactions). Adv. Electrochem. Electrochem. Eng. 1966, 4, 249-371.

12. Jortner, J., Temperature Dependent Activation Energy for Electron Transfer between Biological Molecules. J. Chem. Phys. 1976, 64, 4860-4867.

13. Rubtsov, I. V.; Susumu, K.; Rubtsov, G. I.; Therien, M. J., Ultrafast Singlet Excited-State Polarization in Electronically Asymmetric Ethyne-Bridged Bis (Porphinato)Zinc(II) Complexes. J. Am. Chem. Soc. 2003, 125, 2687-2696.

14. Frisch, M. J.; Trucks, G. W.; Schlegel, H. B.; Scuseria, G. E.; Robb, M. A.; Cheeseman, J. R.; Scalmani, G.; Barone, V.; Petersson, G. A.; Nakatsuji, H. et al., Gaussian 16, Revision A. 03, Gaussian. Inc., Wallingford CT 2016.

15. Angeli, K. A. C.; Bak, K.; Bakken, V.; Bast, R.; Boman, L.; Christiansen, O.; Cimiraglia, R.; Coriani, S.; Cukras, J.; Dahle, P., et al., Dalton2018. 2, See http://Daltonprogram.Org.

16. Aidas, K.; Angeli, C.; Bak, K. L.; Bakken, V.; Bast, R.; Boman, L.; Christiansen, O.; Cimiraglia, R.; Coriani, S.; Dahle, P. et al., The Dalton Quantum Chemistry Program System. Comput. Mol. Sci. 2014, 4, 269-284.

17. Furche, F.; Ahlrichs, R.; Hättig, C.; Klopper, W.; Sierka, M.; Weigend, F., Turbomole. Comp. Mol. Sci. 2014, 4, 91-100. 